\title{
5. PALEOGEOGRAPHY AND TECTONIC EVOLUTION OF THE EASTERN TETHYSIDES: IMPLICATIONS FOR THE NORTHWEST AUSTRALIAN MARGIN BREAKUP HISTORY1
}

\author{
Naci Görür ${ }^{2}$ and A.M.C. S̨engör ${ }^{2}$
}

\begin{abstract}
One of the most significant novelties that came out of the work of Ocean Drilling Program Legs 122 and 123 was that the last major breakup from the northwestern Australian continental margin along the Exmouth, Wombat, and Scott plateaus occurred during the Berriasian-Hauterivian, some $20 \mathrm{~m} . \mathrm{y}$. younger than previously thought. In order to constrain the possible identity of the continental object(s) that departed from this margin, we review the times of continental collision along the suture zones of the Asiatic Tethyside collage, which is the final resting place of the fragments that rifted from northeastern Gondwana-Land since the late Paleozoic. In contrast to most of the current models, our review shows that it is impossible for any of the major continental fragments that now form the Asiatic Tethyside orogenic collage to have rifted off northwestern Australia during the Early Cretaceous because all such fragments had already collided with Asia by that time. On the basis of the similarity of Mesozoic geological record, and following Metcalfe's recent suggestion, the smaller Sikuleh-Natal continental sliver, now located to the southwest of the Woyla suture in Sumatra, plus its possible extensions in northwest Java, are here proposed to be the continental object that left northwest Australia in the Berriasian to Hauterivian time span to open first the Argo and then the Gascoyne abyssal plains. This sliver records an Early Cretaceous extension-related rapid subsidence and final collision with Sumatra along the Woyla suture in the Late Cretaceous.

The northwestern Australian margin contains the record of at least two other major breakup events before the final breakup in the Early Cretaceous. A latest Carboniferous-earliest Permian rifting, which initiated the subsidence of the Westralian superbasin, probably resulted in the departure of the Sibumasu block, the eastern part of the Cimmerian continent comprising the Baoxan area in China, much of western Thailand and eastern Burma, western Malaya, and a bit of central Sumatra. A second rifting is constrained between the Late Triassic and Late Jurassic on the basis of data from northwestern Australia. We suggest that the fragment that left Gondwana-Land during this event was the Lhasa-Central Burma block, including the poorly exposed Mount Victoria Land block in Burma. This identification leads us to think that the second breakup event actually occurred during the latest Triassic, probably in the Rhaetian.

We compare the evolution of northwestern Australia with the east Australian/Tasman Sea region and conclude that in the former region the successive calving of continental strips off the continental margin also occurred in a back-arc setting similar to the evolution of the Tasman Sea region behind the circum-Pacific subduction zones.
\end{abstract}

\section{INTRODUCTION}

One of the more unexpected results of Ocean Drilling Program (ODP) Legs 122 and 123 was the recognition that the breakup of the rifted continental margin of northwest Australia bordering the present Gascoyne and the Argo abyssal plains is substantially younger than previously believed (Leg 122 Shipboard Scientific Party, 1989; Leg 123 Shipboard Scientific Party, 1989; von Rad et al., 1989). Earlier offshore age data had suggested that final breakup and onset of seafloor spreading off the Exmouth and Scott plateaus had commenced in the Callovian-Oxfordian and that spreading in both places had been copolar (Veevers and Heirtzler, 1974, fig. 1). This estimate specifically was based on the deep-sea drilling age data on the oldest recoverable sediment that helped to reassess the previous magnetic anomaly identifications and the age of the ocean floor (Veevers, Heirtzler et al., 1974). Later this estimate was revised on the basis of more detailed seafloor data (Larson, 1977; Larson et al., 1979; Fullerton et al., 1989) and newer initial fits of Australia/India/Antarctica (Veevers, 1988). The best estimates prior to Legs 122 and 123 for the age of onset of seafloor spreading in northwestern Australia were

\footnotetext{
${ }^{1}$ von Rad, U., Haq, B. U., et al., 1992. Proc. ODP, Sci. Results, 122 College Station, TX (Ocean Drilling Program).

${ }^{2}$ Faculty of Mines, Istanbul Technical University, 80626 Ayazağa, Istanbul, Turkey.
}

about $160 \mathrm{Ma}$ (Callovian) for the northern margin of the Exmouth Plateau and $128 \mathrm{Ma}$ (Barremian) for its western margin.

A number of hypotheses were put forward to identify the continental objects that had departed from these margins. Audley-Charles $(1984,1988)$ thought that a continental strip consisting of South Tibet (Lhasa block in Fig. 1: t), Burma, and Malaya (the Sibumasu of Metcalfe, 1986, 1988, 1990, Fig. 1: $\left.\mathrm{s}^{\prime \prime \prime}\right)$ rifted from northwestern Australia in the Late Jurassic. This hypothesis, however, is entirely inconsistent with the geology of the blocks that allegedly make up this fictitious fragment, as shown by Şengör $(1984,1987)$, Şengör et al. (1988), and also summarized below. By contrast, Veevers (1988) partly followed S̨engör (1987) in thinking that Mitchell's (1989) Mount Victoria Land "block" was the continental fragment that had left the Australian northwest margin in the Early Cretaceous (Hauterivian-Valanginian). This hypothesis as conceived by Veevers (1988) is also troublesome because Mitchell's (1989) arguments to separate a Mount Victoria Land block, independent of the Lhasa block, originally to the south of the latter and its possible continuation in Burma are unconvincing, as argued below. Most recently, Metcalfe (1990) proposed that the small continental fragments now aligned south of the Late Cretaceous Woyla suture in Sumatra (e.g., Barber, 1985), plus their possible continuation into northwest Java (including the offshore areas in the Java Sea: Hamilton, 1979, p. 100), and possibly those southeast of the Meratus suture in Borneo (Murphy, 1987), may have been the 


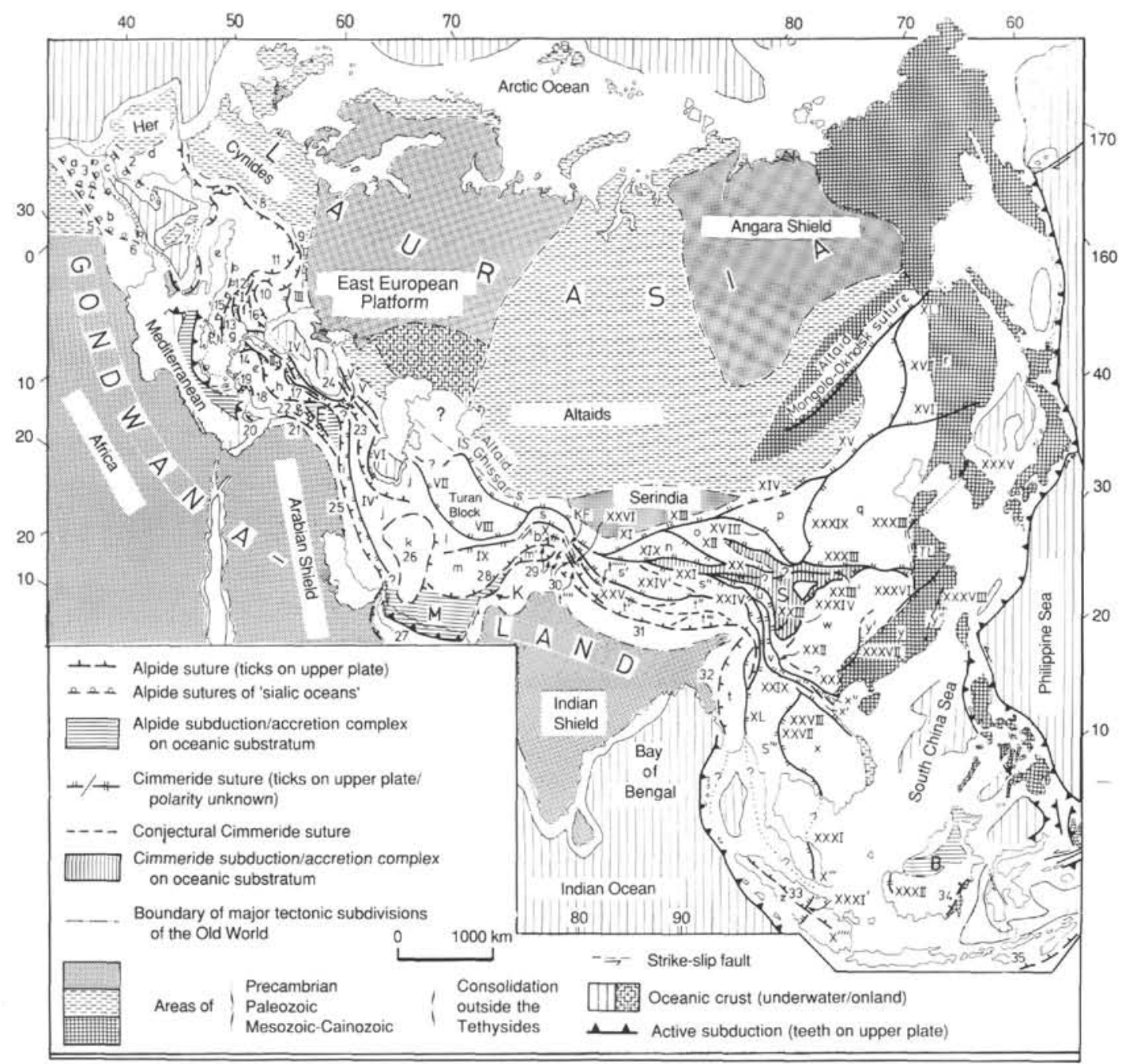

Figure 1. Tectonic map of Eurasia and North Africa, showing their major tectonic subdivisions and the distribution of sutures within the Tethysides. Tethysides correspond with white areas on land. Cimmeride sutures: $\mathrm{I}=$ Paleo-Tethyan suture in Greece and Yugoslavia, $\mathrm{II}=$ Karakaya, III = Luncavita-Consul, IV = North Turkish, IV' = Sanandaj-Sirjan, V = Svanetia, $\mathrm{V}^{\prime}=$ Chorchana-Utslevi, VI = Talesh, VII = Kopet Dagh-Mashhad, VIII = Paropamisus/Hindu Kush/North Pamir, IX = Waser, X = Rushan-Pshart, XI = Northern Kuen-Lun, XII = Qimandag, XIII = Altin Dagh, XIV = Suelun-Hegen Mountains, XV = Inner Mongolian, XVI = Suolun-Xilamulun, XVII $=$ Greater Khingan, XVIII = Tergun Daba Shan/Qinghai Nanshan, XIX = Southern Kuen-Lun, XX = Burhan Budai Shan/Anyemaqen Shan, XXI $=$ Hoh Xil Shan/Jinsha Jiang, XXII = Maniganggo, XXIII = Litang, XXIII' = Luochou "arc-trench belt," XXIV = Banggong Co-Nu Jiang, XXIV' = "Mid-Qangtang," XXV = Shiquan He, XXVI = Southwest Karakorum, XXVII = Nan-Uttaradit/Sra-Kaeo, XXVIII = Tamky-Phueson, XXIX = Song Ma, XXX = Song Da, XXXI = Bentong-Raub, XXXI' = Mid-Sumatra, XXXII $=$ Serebang (West Borneo), XXXIII $=$ Qin-Ling $/$ Dabie Shan, XXXIII' $=$ Northernmost Jiangsu, XXXIV = Longmen Shan/Qionglai Shan, XXXV = Chugareong, XXXVI $=$ Shaoxing-Pingxiang, XXXVII = Tianyang, XXXVIII $=$ Lishui-Haifeng, $\mathrm{XXXIX}=$ Helan Shan, $\mathrm{XL}=$ Mandalay, and XLI $=$ Shilka. Alpide sutures: $1=$ Pyrenean, $2=$ Betic, $3=$ Riff, $4=$ High Atlas, $5=$ Saharan Atlas, $6=$ Kabylian, $7=$ Apennine, $8=$ Alpine, $9=$ Pieniny Klippen Belt, $10=$ Circum-Moesian, 11 = Mureş, 12 = Vardar, $13=$ Peonias/Intra-Pontide, $14=$ Almopias/Izmir-Ankara, $15=$ Pindos-Budva-Bükk, $16=$ Srednogorie, 17 = Ilgaz-Erzincan, $18=$ Inner Tauride, $19=$ Antalya, $20=$ Cyprus, $21=$ Bitlis (Miocene) and Assyrian (Senonian), $22=$ Maden, $23=$ Sevan/Akera/Qaradagh, $24=$ Slate-Diabase zone, $25=$ Zagros, $26=$ Circum-Central Iranian Microcontinent (including Sabzevar and Sistan), $27=$ Oman, $28=$ Waziristan, $29=$ Kohistan $(29$ North $=$ Chalt, 29 South = Main Mantle Thrust $), 30=$ Ladakh $(30$ North $[N]=$ Shyok, 30 South $[\mathrm{S}]=$ Indus), 31 = Indus/Yarlung-Zangbo, $32=$ Indo-Burman, $33=$ Woyla, $34=$ Meratus, and $35=$ Timor. Tethyside blocks: a = Moroccan Meseta, $\mathrm{b}=$ Oran Meseta, $\mathrm{c}=$ Alboran, $\mathrm{d}=$ Iberian, $\mathrm{e}=$ African Promontory (including the Menderes-Taurus block; $\mathrm{e}^{\prime}=\mathrm{Alanya}$ Massif), $\mathrm{f}=$ Rhodope-Pontide, $\mathrm{g}=$ Sakarya, $\mathrm{h}=$ Kırşehir, $\mathrm{i}=$ Sanandaj-Sirjan zone, $\mathrm{j}=$ Northwest Iran, $\mathrm{k}=$ Central Iranian microcontinent, $\mathrm{l}=$ Farah, $\mathrm{m}=$ Helmand, $\mathrm{m}^{\prime}=$ Kohistan, $\mathrm{n}=$ Western Kuen-Lun "Central Meganticlinorium," $\mathrm{o}=$ Qaidam, $\mathrm{p}=$ Alxa (Ala Shan), $\mathrm{q}=$ North China ("Sino-Korean"), $r=$ North China Foldbelt, $s=$ Central Pamir-Qangtang-Sibumasu ( $\mathrm{s}^{\prime}=$ Central Pamir/West Qangtang, $\mathrm{s}^{\prime}=$ East Qangtang, $\mathrm{s}^{\prime \prime \prime}=$ Sibumasu), $\mathrm{t}=$ Lhasa-Central Burma $\left(\mathrm{t}^{\prime}=\right.$ Bongthol Tangla, $\mathrm{t}^{\prime \prime}=$ Nagqu, $\mathrm{t}^{\prime \prime \prime}=$ Lhasa proper [A. Gansser, pers. comm., 1985], $\mathrm{t}^{\prime \prime \prime \prime}=$ Ladakh, $\mathrm{t}^{\prime \prime \prime \prime \prime}=$ West Lhasa-South Pamir), $\mathrm{u}=$ Shaluli Shan, $\mathrm{v}=$ Chola Shan, $\mathrm{w}=$ Yangtze, $\mathrm{x}=$ Annamia (possibly with two exotic island arcs of early $\left[\mathrm{x}^{\prime}\right]$ and late $\left[\mathrm{x}^{\prime \prime}\right]$ Paleozoic age and eastern Malay Peninsula $\left[\mathrm{x}^{\prime \prime}\right]$ and south Sumatra $\left.\left[\mathrm{x}^{\prime \prime \prime}\right]\right)$, y (sensu lato) $=$ Huanan $(y[$ sensu stricto $]$ $=$ Huanan, $y^{\prime}=$ Hunan, $y^{\prime \prime}=$ coastal block), and $z=$ Sikuleh-Natal fragment. Key to lettering: $B=$ Sarawak accretionary complex, b (just southwest of $\mathrm{X})=$ Southeast Pamir black slates, $\mathrm{E}=$ East Anatolian accretionary complex, $\mathrm{KF}=\mathrm{Karakorum}$ fault, $\mathrm{M}=\mathrm{Makran}$ accretionary complex, and TL = Tan-Lu fault. The block and suture designations in this paper follow those in Şengör et al. (1988). 
pieces that had broken off northwest Australia. This suggestion best fits the currently available data, but Metcalfe (1990) presented no geological data either from Sumatra or from the Australian margin to support his hypothesis. It is one of the purposes of this paper to supply the available data from both places with particular emphasis on the stratigraphic results of Legs 122 and 123 in order to corroborate Metcalfe's (1990) view.

Indeed, the results of Legs 122 and 123 place entirely new constraints on the identity of the continental objects that formed a part of the northwest Australian continental margin until the late Mesozoic by revising the precise timing of the various rifting events and the final breakup along this margin and documenting their detailed geological record (e.g., von Rad et al., 1989, fig. 13). It now seems that the opening of the Argo Abyssal Plain was some $20 \mathrm{~m}$.y. younger than previously supposed, during the Berriasian-Valanginian, and the breakup along the western margin of the Exmouth Plateau was probably near the end of the Neocomian with a Hauterivian breakup unconformity (Leg 122 Shipboard Scientific Party, 1989; Leg 123 Shipboard Scientific Party, 1989; von Rad et al., 1989). These ages effectively dispose of Audley-Charles's (1984, 1988) hypothesis, although both Veevers' (1988) and Metcalfe's (1990) hypotheses remain as viable alternatives when viewed from the vantage point of the geology of the northwestern Australian margin and the adjacent piece of Mesozoic ocean floor. The purpose of this contribution is to look at the tectonics of the Asiatic Tethysides (cf. Szengör, 1987) with a view to constraining the identity of the continental objects whose Early Cretaceous departure from northwest Australia created the present continental margin.

In the following pages we first discuss the methodology we adopted to justify our rationale and to indicate our possible error limits. We then review the suture and block distribution and the paleogeography and tectonics of the Asiatic Tethysides and compare the relevant parts with northwest Australia.

\section{METHODOLOGY AND SOURCES OF ERROR}

In order to constrain the identity of the continental piece(s) that left northwest Australia in the earliest Cretaceous (Neocomian-Barremian interval), the methodology we adopt here is to look at the timing of collisions along sutures in the Asiatic Tethyside orogenic collage, the most likely resting place of the pieces that departed from northern Gondwana-Land in the northwest Australian sector. The extant ocean-floor data on magnetic lineations and fracture zones (Norton and Sclater, 1979; Veevers, 1984; Gahagen et al., 1988; Scotese et al., 1988; Cande et al., 1989) make it unlikely that any continental pieces that left northwest Australia in the middle to late Mesozoic could have gone anywhere except to South or Southeast Asia (see also Rowley et al., 1986). Regional paleogeographic and paleomagnetic arguments make a similar conclusion likely for those pieces that may have departed in the Permian to Late Jurassic inclusive (e.g., Sengör, 1979; Bunopas, 1981; Ridd, 1980; Stauffer, 1983, 1985; Şengör and Hsü, 1984; Barber, 1985; Rowley et al., 1986; Metcalfe, 1988, 1990; Audley-Charles, 1988; Hutchison, 1989a, 1989b; Bunopas and Vella, 1989; Bunopas et al., 1989a, 1989b). The rationale for our method, therefore, is that any pieces that have sutured to Asia before the Cretaceous could not have departed from Australia during the Cretaceous. The rates of Cretaceous seafloor spreading as obtained from the magnetic anomalies in the Gascoyne and Cuvier abyssal plains (approximately $5 \mathrm{~cm} / \mathrm{yr}$ : see Cande et al., 1989) and the precise time of breakup off the Exmouth Plateau during the Neocomian make it unlikely (assuming constant spreading rate) than any of the blocks that sutured to Asia in the latest Jurassic-middle
Cretaceous interval may be identical with the piece(s) that left Australia in the Early Cretaceous, for this would have required a minimum $60-\mathrm{m} . \mathrm{y}$. transit time as opposed to the maximum $25 \mathrm{~m} . \mathrm{y}$. that is available.

As we show in the next section, this logic considerably reduces the number of blocks in the Asiatic Tethysides that may have rifted from northwestern Australia in the Early Cretaceous. The next step is to compare the geological history of the remaining continental pieces with that of northwest Australia, and more specifically, with the history of its marginal submerged plateaus, such as the Exmouth, Wombat, and Scott, between the late Permian and middle Cretaceous, during which one protracted phase (or many distinct phases) of rifting characterized this margin. We use the same principle of elimination and comparison in identifying the blocks that moved away from Australia in the earlier episodes of rifting as long ago as the Permian that "set the scene" for the Early Cretaceous rifting. Rifting episodes earlier than the Permian are not considered here for two reasons. They are less relevant to the problem of the origin and evolution of the northwest Australian margin. Much larger blocks with more equidimensional aspect (such as North China and Yangtze/ eastern Qangtang) than the continental "strips" that rifted later had formed during these earliest rifting events, which possibly betrays a different mode of rifting than the later events. Also the final destinations of these earlier rifted pieces are less well constrained (cf. Burrett and Stait, 1987).

Although simple in principle, the procedure outlined above is wrought with difficulties stemming from a number of uncertainties. They form the sources of error in our arguments and are listed below:

1. The locations and ages of closure along some of the Tethyside sutures are still a matter of dispute. There is now little doubt that all Tethyside sutures except 33 and 34 (Fig. 1) closed before the middle Cretaceous (Aptian-Albian, but see Audley-Charles, 1988), but there is considerable disagreement as to when some of the South Chinese and Indochinese sutures closed. Although the range of uncertainty in these earlier closure times (early Carboniferous to Late Triassic, cf. Hutchison, 1989a, 1989b; Metcalfe, 1990; but see AudleyCharles, 1988) does not affect the identification of the pieces that rifted from Australia in the Early Cretaceous, they may introduce errors into the interpretation of the earlier rifting episodes.

2. The paleogeography of the individual Tethyside blocks is not in all cases well established. Although the larger blocks such as Yangtze (w), North China (q), Lhasa-Central Burma $(\mathrm{t})$, East Qangtang $\left(\mathrm{s}^{\prime \prime}\right)$, Sibumasu $\left(\mathrm{s}^{\prime}\right)$, and Annamia (x) are relatively well known, little data exist from the smaller pieces such as the Shaluli Shan (u) and the Chola Shan (v) "arcs" or the Sikuleh $\left(z^{\prime}\right)$ and Natal $\left(z^{\prime \prime}\right)$ slivers or, indeed, the relatively larger block of Huanan (y). In some cases, such as in the Huanan block, the existing data themselves are disputed (e.g., Rowley et al., 1989; Hsü et al., 1989). Owing to these uncertainties our interpretations have variable reliability depending on which blocks are involved. This introduces considerable error margins into the comparison of the geological history of some of the blocks with that of the northwestern Australian margin.

3. Uncertainty resulting from paucity of data also applies to paleomagnetic information. Some blocks are relatively well sampled, but from others there are no paleomagnetic data at all, making the establishment of a "drift path" impossible.

In the following sections we present a synthesis of the available data from the Tethyside collage. We first identify the sutures and the blocks stitched together by them and then 
summarize the stratigraphic data for the late Permian to middle Cretaceous of the individual Tethyside blocks.

\section{SUTURES AND BLOCKS IN THE TETHYSIDE OROGENIC COLLAGE}

Figure 1 is a map showing the distribution of sutures and blocks in the Tethyside orogenic collage. For the details regarding the placement of the sutures in the following account and the relevant references, see Sengör $(1984,1987)$, S̨engör and Hsü (1984), and Şengör et al. (1988), although a number of details are herein changed from those publications in the light of newer data and ideas. A discussion of these changes overflow the boundaries of this paper, however. Most of the blocks involved were originally located in GondwanaLand, defined as the southern supercontinent assembled during the Pan-African collisions ( $900-400 \mathrm{Ma}$ ) (Sengör, 1986a, 1987; Sengör et al., 1988). Within the Tethyside collage two groups of sutures are known. One group, called the Cimmeride sutures, resulted from the closure of the various branches of Paleo-Tethys, the original, eastward widening triangular gulf extending into late Paleozoic Pangaea, dividing it into a northern Laurasia and a southern Gondwana-Land. The blocks stitched together by the Cimmeride sutures form the Cimmeride orogenic collage (Sengör, 1986a). The second, much smaller group is the product of the closure of NeoTethys. The sutures of this group weld together and onto Eurasia the blocks forming the Alpide orogenic collage. The Cimmeride and the Alpide collages together constitute the Tethyside orogenic collage (Sengör, 1987).

The oldest suture within the Cimmerides (but probably unrelated to Cimmeride tectonism) is the Devonian TamkyPhueson suture (XXVIII) in North Vietnam, which may have resulted from the collision of an island $\operatorname{arc}\left(\mathrm{x}^{\prime}\right)$ with what is today Annamia (x). The next oldest suture is just north of the Tamky-Phueson structure along the Song Ma River (XXIX) and is of early Carboniferous age. It resulted either from the collision with Annamia (by then enlarged by the earlier accretion of $\left.\mathrm{x}^{\prime}\right)$ of another island arc $\left(\mathrm{x}^{\prime \prime}\right)$ (Sengör, 1984, 1987; Sengör et al., 1988) or of the Yangtze block (or "South China block" at large: cf. Hutchison, 1989b; Metcalfe, 1988, 1990). We prefer the first interpretation because the Triassic deposits under the unconformable Norian molasse (Burrett, 1974) display a strong deformation with pronounced north vergence, resembling subduction-accretion complexes (e.g., see Fromaget, 1934, cross-section in plate VIII), and greenschist metamorphism affecting arc volcanics (metaandesites and metadacites) and clastic sedimentary rocks (Phan and Tran, 1989), suggesting that a still later collision succeeded the early Carboniferous deformation.

Late Carboniferous-Permian sutures are all in the north and weld the North China (q), Alxa (p), and the "North China Foldbelt"' (r) blocks to the late Paleozoic Asia.

The Kuen-Lun mountain range consists of an immense Paleozoic to earliest Mesozoic accretionary complex that began forming in pre-Devonian time and ended in the latest Triassic by the collision of the Qangtang blocks ( $\mathrm{s}^{\prime}$ and $\left.\mathrm{s}^{\prime \prime}\right)$ with it. Latest Triassic was also the time of final apposition of the North China block (q) with the Yangtze block (w) along the Qin-Ling suture (XXXIII).

Late Triassic-Jurassic time saw the closure of the Xiangganzhe ocean along the Shaoxing-Pingxiang (XXXVI) and the Tianyang sutures (XXXVII), although this timing is disputed by some (e.g., Rowley et al., 1989; Charvet and Faure, 1989). AMCS saw the Shaoxing-Pingxiang suture in the field both in the Zhejiang and Jiangxi provinces of the People's Republic of China. The presence of Permian pillow lavas in close field proximity to ultramafics and gabbros, and the presence of
Triassic flysch and molasse deposits affected by strong deformation inferred to be under unconformable Jurassic terrestrial sequences, and the absence of a purported Devonian unconformity (Rowley et al., 1989) crossing the proposed site of the suture (e.g., a conformable succession from a dirty Silurian sandstone with much shale and mica flakes into upper Devonian quartzites followed by brachiopod-bearing dark brownblack sandstones near the Chen Cuen village, southern Anhui: AMCS), convinced him that the suture is indeed of Late Triassic age. We follow this interpretation here also.

In Indochina most terminal sutures are of Middle to Late Triassic age, although in recent years ages of terminal suturing between the Carboniferous (e.g., Helmcke, 1983) and the Early Triassic (e.g., Harbury et al., 1990; Metcalfe, 1990) have been proposed. Şengör (1986b) discussed the reasons for keeping the age of collision along the Nan-Uttaradit (XXVII) and the Bentong-Raub (XXXI) sutures Middle to Late Triassic. Recently, Harbury et al. (1990) presented detailed field observations that allegedly show a late Permian age for the Bentong-Raub suture. Harbury et al.'s (1990) arguments are based mainly on the following pieces of evidence:

1. The Jurassic to Early Cretaceous Tembeling Group (as redefined by Harbury et al., 1990) rests across an angular unconformity at the Jengka Pass on steep middle Permian rocks.

2. The multiphase deformation along the northern highway between Jeli and Grik in Malaysia predates granites that are supposed to be of Permian-Triassic age according to Cobbing et al. (1986).

However, at the Jengka Pass, the volcaniclastic Kerum Formation is missing, and therefore the dating of the deformation is not as narrowly constrained as Harbury et al. (1990, p. 13) assert. Moreover, there are no granites older than the Late Triassic in the Main Range and the Central Belt (Liew and Page, 1985; Cobbing et al., 1986), and therefore the deformation along the northern highway is only older than about $220 \mathrm{Ma}$ (Norian). In the detailed field report of Harbury et al. (1990) we thus were unable to find any convincing evidence for a purported late Permian deformation in the Malay Peninsula. What they do document in that paper is a possible lower limit for the age of the pre-Tembeling (in the old sense) deformation. Similarly, in the more recent accounts (e.g., Tran, 1986; Hutchinson, 1989a, 1989b; Metcalfe, 1988, 1990) we have been unable to find any compelling reason to alter the age of terminal collision along the Song Da suture (XXX) from the middle to Late Triassic as originally proposed by S̨engör $(1979,1984)$. In fact, more recent data on Triassic greenschist metamorphism associated with compressional deformation (see above) rather support the Triassic age for the terminal collision.

North and northeast of the Qangtang block ( $\mathrm{s}^{\prime}$ and $\left.\mathrm{s}^{\prime \prime}\right)$ the Songpan-Ganzi accretionary complex (S: Sengör, 1981, 1984) represents a giant "suture knot" filled with sparse late Permian deep-sea sedimentary rocks and mainly Triassic ophiolitic mélange, flysch, and molasse deposits. In this region mostly medial and Late Triassic sedimentary rocks are present. They consist predominantly of bathyal and neritic clastic rocks deposited by turbidity currents and perhaps redistributed by contour currents developed mainly as flysch with intercalated mafic and felsic volcanics and molasse, respectively. The latest Permian-Triassic sedimentation in the Songpan-Ganzi System was one of basin filling and shallowing, culminating in the paralic Upper Series of the latest Triassic.

Southwest of the Songpan-Ganzi System there are three magmatic arcs. The arc next to the Songpan-Ganzi System (S) 


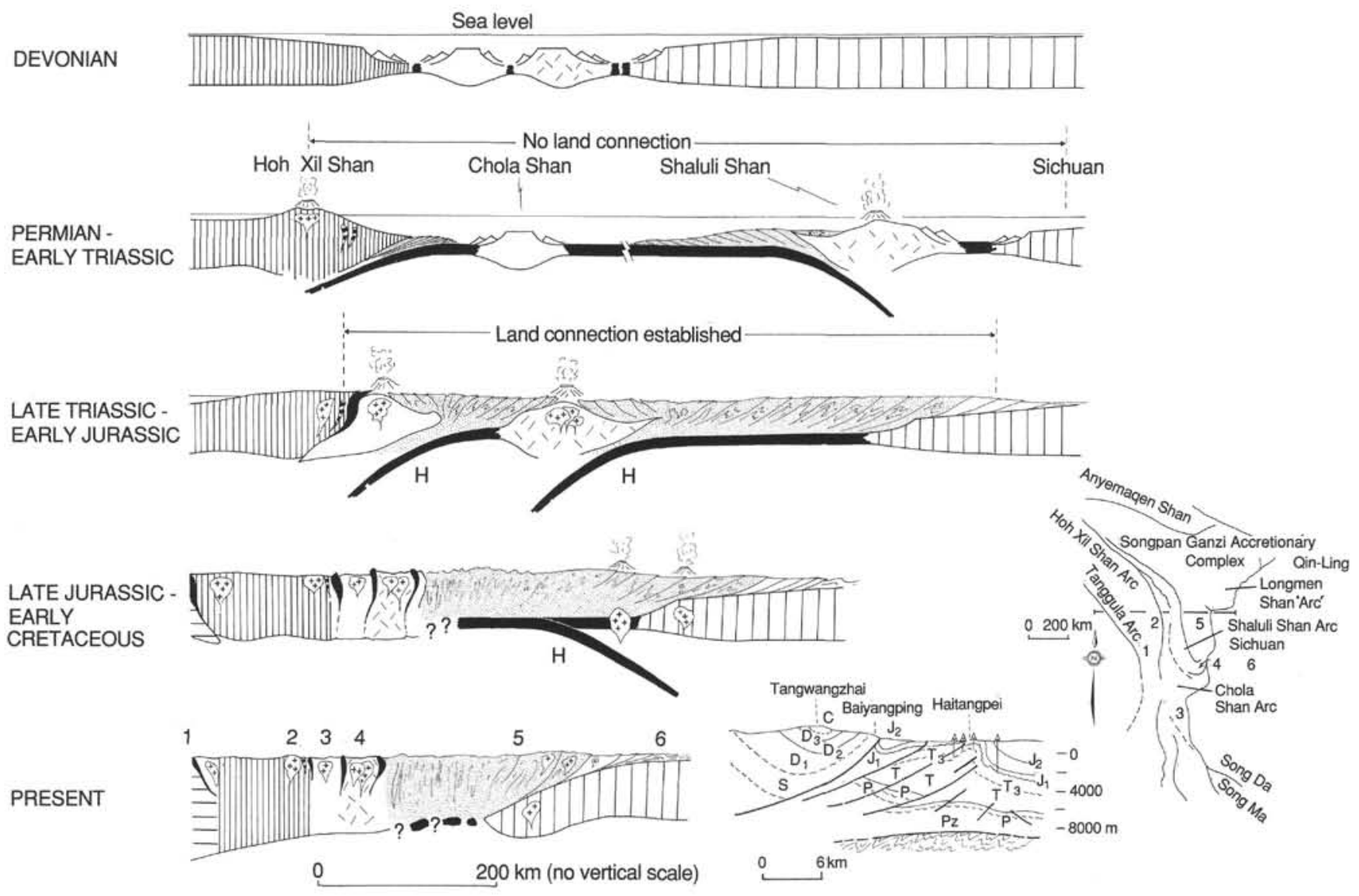

Figure 2. Evolution of the Songpan-Ganzi System and its marginal arc system along an east-west cross-section. Key to the lettering: $\mathrm{H}=\mathrm{Hidden}$ subduction, $\mathrm{Pz}=$ Paleozoic, $\mathrm{S}=$ Silurian, $\mathrm{D}_{1}=$ lower Devonian, $\mathrm{D}_{2}=$ middle Devonian, $\mathrm{D}_{3}=$ upper Devonian, $\mathrm{C}=\mathrm{Carboniferous}, \mathrm{P}=$ Permian, $T=$ Triassic, $T_{3}=$ Upper Triassic, $J_{1}=$ Lower Jurassic, $J_{2}=$ Middle Jurassic. (Modified from S̨engör and Hsü, 1984).

is called the Shaluli Shan arc (u) and was active between the Permian and the Early Cretaceous. West of the Shaluli Shan is the Chola Shan arc (v) whose activity extended between the Jurassic and the Early Cretaceous. Figure 2 shows the evolution of the Songpan-Ganzi System and its marginal arc systems along an east-west cross-section.

Following a presumed Devonian rifting event, subduction of Paleo-Tethys began in the early Permian both beneath the Hoh Xil Shan and the Yangtze block (w), of which the Shaluli Shan (u) arc, possibly together with the East Qangtang block $\left(s^{\prime \prime}\right)$, then formed the marginal part, although this is not depicted in this cross-section. It rifted from the Yangtze block (w) in Permian time and became an ensialic island arc. By the Late Triassic, the Shaluli Shan (u) had collided with the Chola Shan (v) (across XXII) and the Chola Shan (v) had been apposed against the Hoh Xil Shan (across XXI). This led to a polarity reversal of the subduction under the Shaluli Shan (u) and the Permian back-arc basin between the Shaluli Shan (u) and the Yangtze $(w)$ block began contracting. The rich terrigenous influx into this basin mainly from the Kuen-Lun/Qin Ling (XXXIII) orogenic belts rapidly filled this basin forming (an) immense subduction-accretion complex(es) that largely surfaced by the latest Triassic. Although this led to a cessation of marine sedimentation in the entire Songpan-Ganzi System, its constriction by the convergence of the Yangtze (w) and the eastern Qangtang ( $\left.\mathrm{s}^{\prime \prime}\right)$ blocks, plus the latter's collage of two arcs, led to further removal of oceanic lithosphere well into the "Jurassic" beneath the accretionary complex in a "hid- den" or "subcutaneous" fashion (S̨engör, 1984; S̨engör and Hsü, 1984), giving rise to the anomalous occurrence of arc magmatic rocks amidst terrestrial environments. Sparse Cretaceous magmatic rocks here probably resulted from the thickening and partial melting of the lower levels of the collided aggregate.

The West Qangtang block ( $\left.\mathrm{s}^{\prime}\right)$ also collided with the western Kuen-Lun accretionary complex sometime in the Late Triassic-Early Jurassic interval, but the record along this suture is very incomplete, possibly owing to post-collisional strike-slip elision of pieces out of the suture zone. The Chasa suture $\left(\mathrm{XXIV}^{\prime}\right)$ separating eastern $\left(\mathrm{s}^{\prime \prime}\right)$ and western Qangtang $\left(s^{\prime}\right)$ blocks may have closed synchronously with the collision of the two blocks with Eurasia.

Along the Banggong Co-Nu Jiang suture zone (XXIV) a Late Jurassic supra-subduction-zone ophiolite obduction on a massive scale onto the Lhasa block $(\mathrm{t})$ was followed by the collision of the Lhasa block (t) with the Qangtang blocks (s) in pre-Aptian-Albian time (Girardeau et al., 1984a; Chang et al., 1986; Pearce and Deng, 1988; for the western segment see Henning, 1915; Baud, 1989). The collision along the southern continuation of the Banggong Co-Nu Jiang suture (XXIV), viz. the Mandalay or Sagaing suture (XL), also occurred in the Early Cretaceous (Metcalfe, 1988).

In Burma, the position of the Mount Victoria Land block (Mitchell, 1989) is unclear. Mitchell (1989) considers it tectonically in an equivalent position to India and separates it from a hypothetical extension of the Lhasa block in Burma, now 
hidden beneath the central Burmese lowlands, along an ophiolitic suture of middle Cretaceous age. In Mitchell's (1989) interpretation, quartzose turbidites and carbonaceous mudstones, with minor limestone and cherts of Carnian age overlying across a thrust contact of biotite and biotite graphite schists with intercalated greenstones and marble (presumed Mount Victoria Land basement), play a central role. $\mathrm{He}$ considers the Carnian sedimentary rocks to be the equivalents of the Triassic continental slope/apron turbidites in the Tethyan Himalayas and thus envisages a position for them south of in the Lhasa block (t). However, similar Triassic rocks also exist on the Lhasa block (t). For instance, the counterparts of the Triassic turbidites in the Tethyan Himalayas exist to the immediate north of the Indus-Yarlung Zangbo suture (31) in the Zangbo region. Moreover, CarnianNorian "flysch" is represented by the Longjiexue Group in the eastern part of the Yarlung Zangbo suture (Chang et al., 1989).

Triassic clastic rocks also exist along the northern margin of the Lhasa block (t), especially east of $94^{\circ} \mathrm{E}$ and south of $32^{\circ} \mathrm{N}$ (Chengdu Institute of Geology and Mineral Resources, 1989) and also in the Nagqu area (Chang et al., 1989), but detailed descriptions of these rocks are not now available for a comparison with the Carnian sedimentary rocks of the Burmese area.

What overlies the Carnian rocks in Burma is totally dissimilar to what is known from the Himalayas, but resembles greatly the conditions known from the Banggong Co-Nu Jiang suture zone near Dongqiao (e.g., Girardeau et al., 1984a; Dewey et al., 1988). Serpentinized harzburgite with hornblende pegmatite veins and areas of pillow lavas, minor massive lava, gabbro, and dolerite are unconformably overlain by a basal conglomerate of Aptian-Albian age. This conformably passes into carbonaceous ammonite-bearing limestones and black pyritic mudstones and shales containing rare serpentine-bearing sand layers. Near the top of this sequence an Albian age was obtained (Mitchell, 1989). In northern Burma, a similar picture is seen near Mandalay along the southern continuation of the Banggong Co-Nu Jiang suture: jadeite-albite dykes and glaucophane schists among large outcrops of ophiolites unconformably overlain by Albian limestones (Mitchell, 1981). This clearly suggests a pre-middle Cretaceous ophiolite obduction onto the Carnian sedimentary rocks, thus probably coeval with the obduction onto the Lhasa block ( $\mathrm{t}$ ) along the Bangnong $\mathrm{Co}-\mathrm{Nu}$ Jiang suture (XXIV). We thus interpret the Mount Victoria Land block to be a part of the Lhasa fragment (t) (cf. Sengör, 1987) and not an independent continental piece as envisioned by Mitchell (1989) and Veevers (1988). Where the suture of the Banggong Co-Nu Jiang (XXIV) goes farther south is at present unclear, but we follow Şengör (1984) in taking it into the Malacca Strait between peninsular Malaysia and Sumatra.

The Banggong Co-Nu Jiang ocean was the last PaleoTethyan branch to close. Younger closures all destroyed parts of Neo-Tethys in Asia, as, for example, the closure of the Chalt-Shyok $\left(29^{\circ} \mathrm{N}\right.$ and $\left.30^{\circ} \mathrm{N}\right)$ and the Waziristan-Main Mantle Thrust (Kohistan south suture: 29)-Indus-Yarlung Zangbo sutures (31) around the Indian subcontinent.

In Southeast Asia, the only two segments of a later suture are the Woyla suture (33) in Sumatra (Cameron et al., 1980) and the Meratus suture (34) in southeast Borneo (Murphy, 1987). Until recently the Woyla suture (33) was considered to mark the site of a now-closed marginal basin that was hypothesized to have opened in the Late Jurassic and closed in the Late Cretaceous (e.g., Cameron et al., 1980). New evaluation of older paleomagnetic data from the Sikuleh fragment $\left(z^{\prime}\right)$ southwest of the Woyla suture (34) (Haile, 1979) suggests that the Sikuleh and probably also the Natal fragments $\left(\mathrm{z}^{\prime \prime}\right)$ may represent pieces broken off the northern margin of GondwanaLand that remained in the Southern Hemisphere until Early Cretaceous time (Metcalfe, 1990).

The Meratus suture (34) represents an arc-continent collision of Cenomanian age (Murphy, 1987, and references cited therein) and is interpreted by Metcalfe (1990) as a continuation of the Woyla suture (33) in Sumatra.

In the tectonic collage of Southeast Asia, there is one more region that probably was located originally near northwestern Australia. It is the Hainan Island $\left(\mathrm{s}^{\prime \prime \prime \prime}\right)$ in the Gulf of Tonkin. Recent field studies here have shown that the island consists of two assemblages, namely Qiongzhong and Yaxian (Yu et al., 1988; Yu, 1989). Metcalfe (1990) pointed out that the Paleozoic sequences in these assemblages are similar to those in northwestern Australia yielding trilobites and other invertebrate fossils endemic to Australia and Gondwana-Land. The sequence also includes lower Permian glacial-marine diamictites. Paleomagnetic data from the Yaxian assemblage gives a Cambrian paleolatitude of $6.7^{\circ} \mathrm{S}$, which is consistent with derivation from the Australian part of Gondwana-Land, although a Permian paleolatitude of $5^{\circ} \mathrm{N}$ from the Qiongzhong assemblage appears in conflict with an Australian origin and would remain so even if it were $5^{\circ} \mathrm{S}$. However, on the strength of the stratigraphic evidence, we consider the Hainan Island a part of Sibumasu. Figure 3 shows our tentative interpretation of how it might have attained its present location amidst entirely foreign terrains.

In the following section, we summarize the paleogeography of the blocks constituting the Asiatic Tethyside collage for the late Permian (Kazanian-Tatarian), Late Triassic (Norian-Rhaetian), Late Jurassic (Kimmeridgian-Tithonian), and Early Cretaceous (Aptian-Albian) intervals. These intervals represent critical breakup episodes in northwestern Australia.

\section{REGIONAL STRATIGRAPHY AND PALEOGEOGRAPHY OF THE ASIATIC TETHYSIDES BETWEEN THE LATE PERMIAN AND MIDDLE CRETACEOUS}

Late Permian (Kazanian-Tatarian: Figs. 4 and 5)

During the late Permian, the East Qangtang $\left(\mathrm{s}^{\prime \prime}\right)$-Yangtze (w), Huanan (y), Annamia (x), and Central Pamir-West Qangtang-Sibumasu (s) blocks were independent continents separated from one another and from the Laurasian mainland by the various branches of the Paleo-Tethys ocean (Figs. 4 and 5). The Alxa (p)-North China (q) block had just collided with an appendage of Asia and the Qaidam (o) accretionary complex had become a part of the same appendage, together constituting the Tethyside blocks east of the Pamirs that had already been added to the Laurasian mainland and were forming part of its southern Asiatic margin. They were largely the depositional sites for continental to shelf sediments passing oceanward into deep-marine siliciclastic muds and radiolarian cherts in the Songpan-Ganzi region (Figs. 4 and 5). The continental sedimentary rocks on these blocks comprise red, brown, and yellow sandstones, conglomerates, shales, marls, and limestones intercalated in part with coal beds and evaporites (Lexique, 1963, 1971). Parts of the western Kuen-Lun (n) and Qaidam (o) were probably an erosional land area at this time (Fig. 4). The shelf areas deposited brachiopod- and coral-bearing bioclastic limestones with associated sandstones, siltstones, conglomerates, and tuffs in part (Jixiang et al., 1988). In the southern Alxa (p) and eastern Qaidam (o), the marginal marine areas were characterized by the deposition of brown to black shale, sandy shale, green sandstone, and limestone with coal intercalations (Fig. 4). 


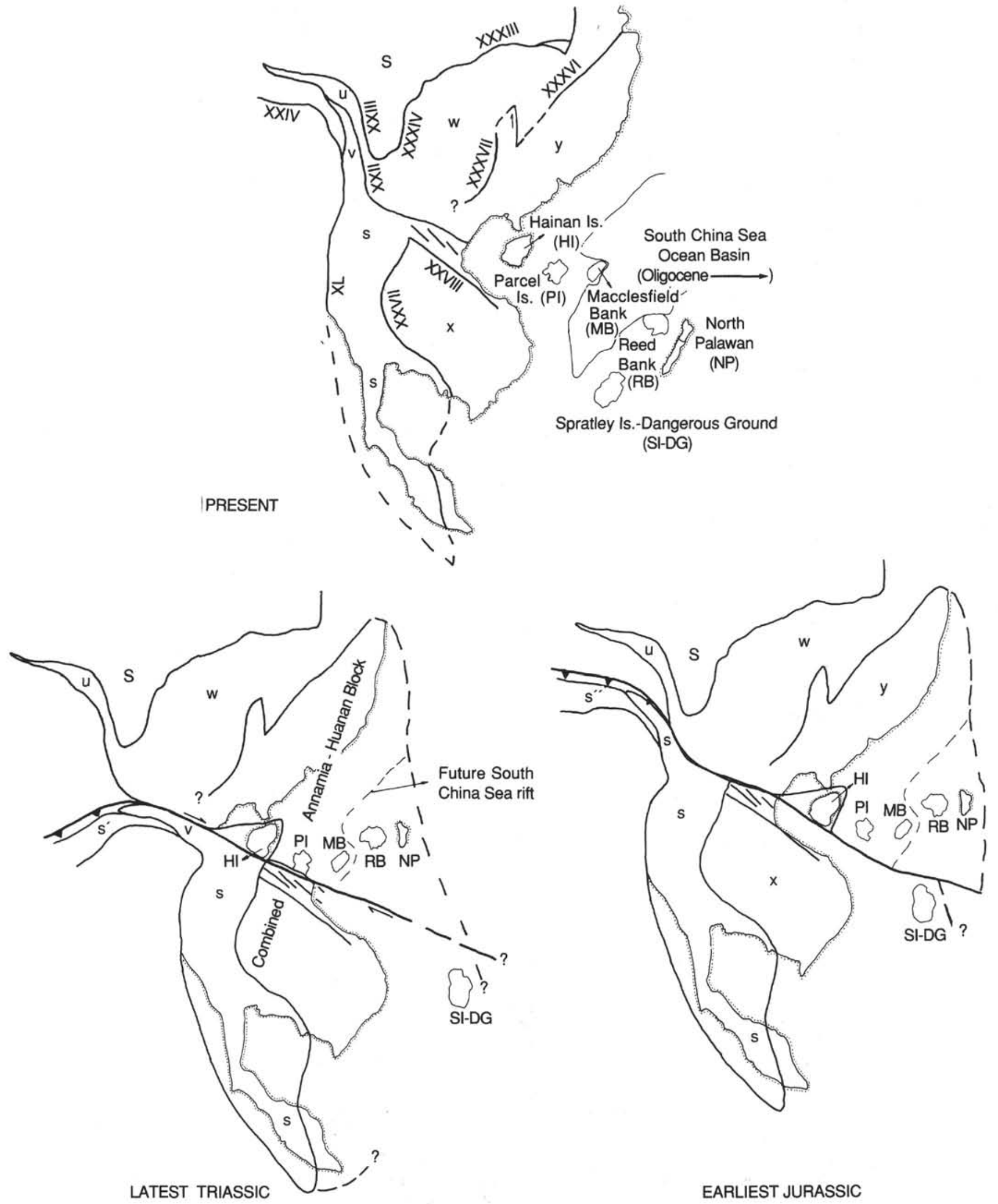

Figure 3. Sketch maps showing the separation of Hainan Island from the rest of the Sibumasu block. For abbreviations see Figure 1. 


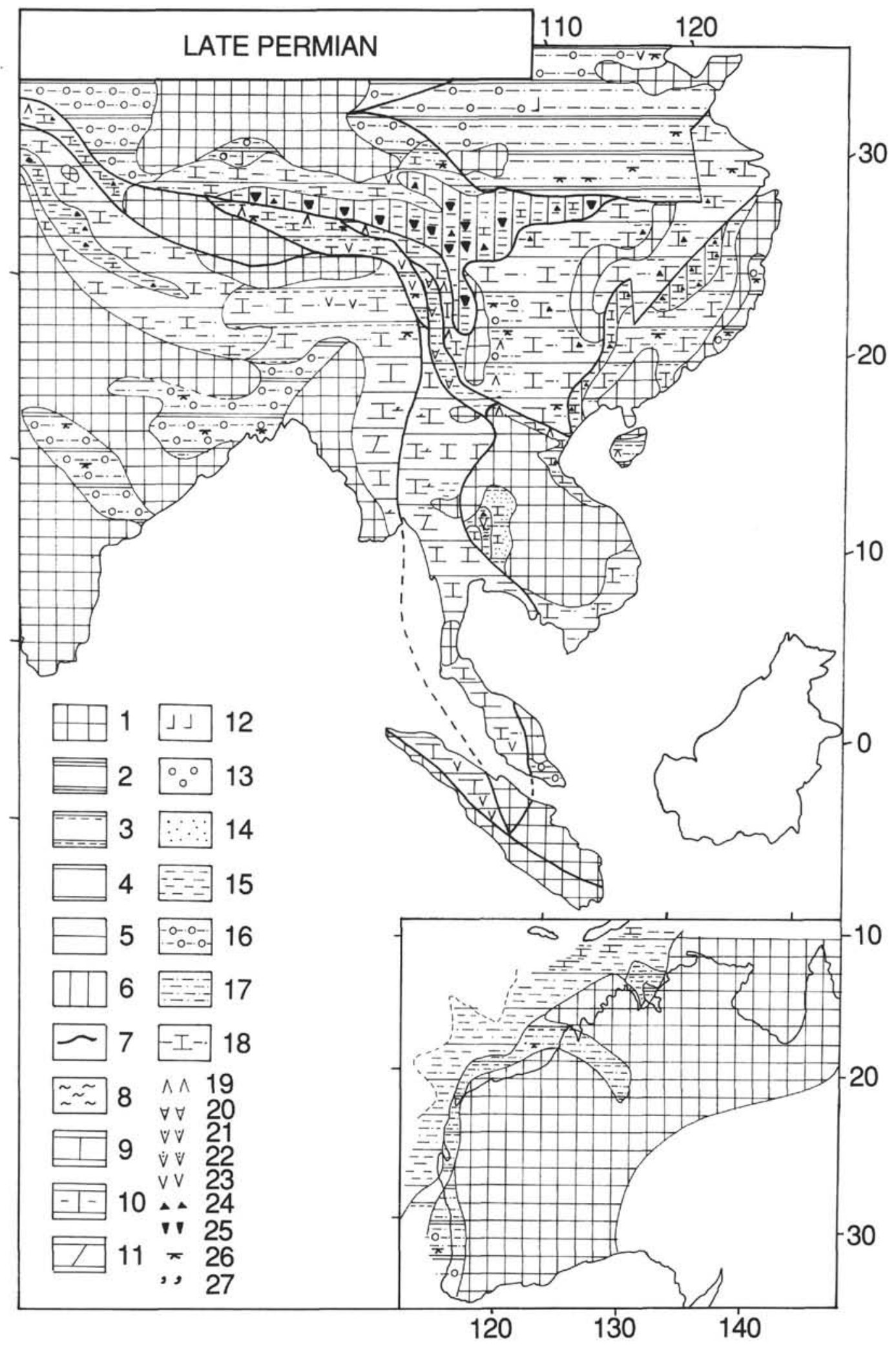

Figure 4. Non-palinspastic late Permian paleogeographic map of the eastern Tethys (main sources from which this map was compiled are cited in text). Legend: $1=$ land and/or erosional area; $2=$ continental; $3=$ marginal marine; $4=$ shelf; $5=$ intrashelf basin; $6=$ continental slope; $7=$ ocean (suture zone) $8=$ turbidites (terrigenous and carbonates with deep-water carbonates, flysch); $9=$ limestone; $10=$ marl, clayey limestone; $11=$ dolomite; 12 = evaporite; 13 = conglomerate $; 14=$ sandstone; $15=$ shale $; 16=$ conglomerate, sandstone, shale; $17=$ sandstone, shale; $18=$ carbonate and clastic rocks; $19=$ basalt, basic volcanics; $20=$ andesite; $21=$ acidic volcanics; 22 = trachyte $23=$ volcanics; $24=$ cherty; $25=$ chert, radiolarite; $26=$ coal, plant remains; and 27 $=$ glauconite, phosphate. 


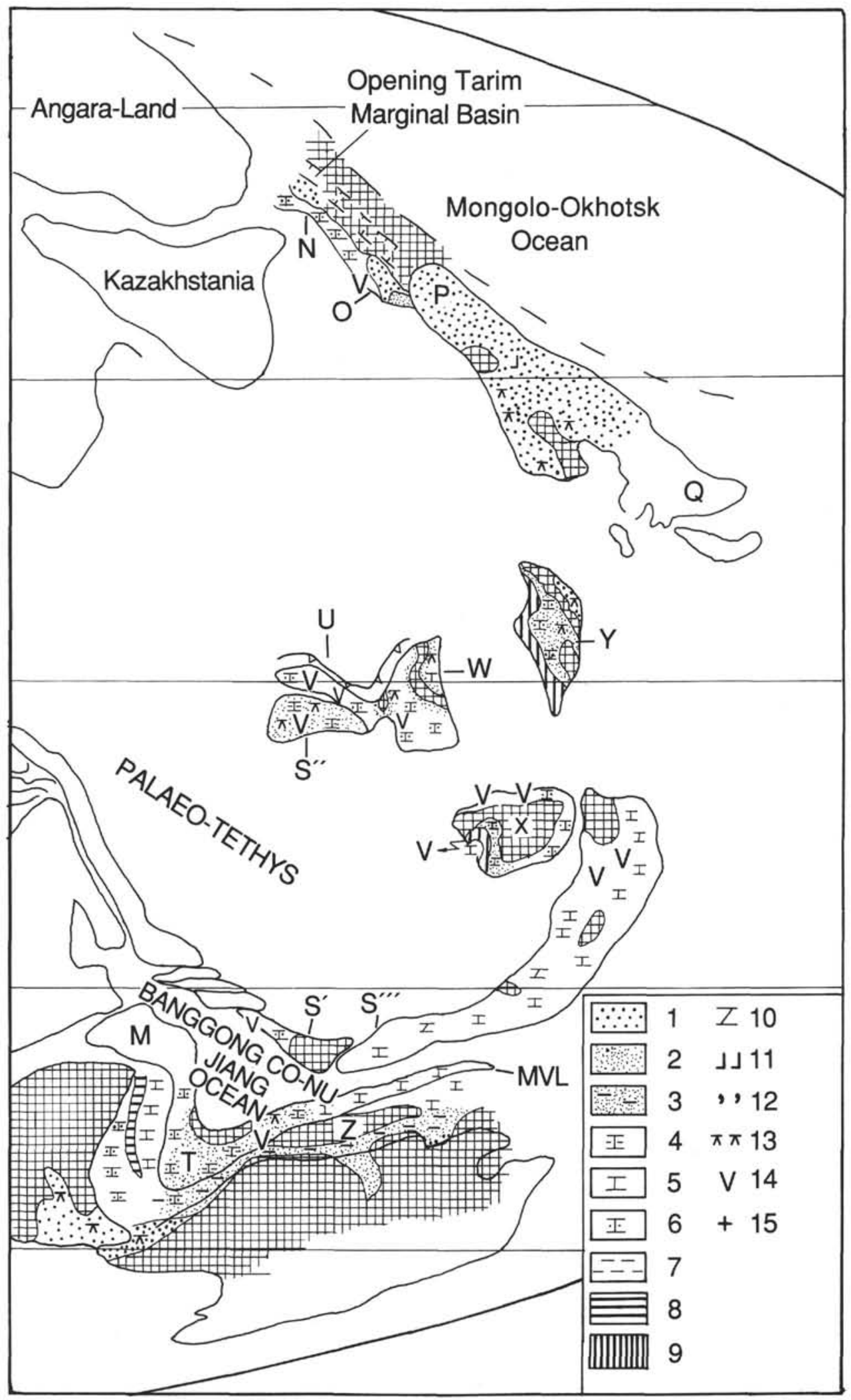

Figure 5. Late Permian paleotectonic sketch map of the eastern Tethys. (Distribution of the main continents is taken from Scotese et al., 1987). Legend: $1=$ continental clastic rocks; $2=$ marginal marine clastic rocks; 3 = marginal marine to shelf clastic rocks; $4=$ marginal marine carbonates; $5=$ shelf carbonates; $6=$ shelf carbonates and associated clastic rocks; $7=$ shelf shale; $8=$ intrashelf basinal carbonates and clastics; $9=$ continental slope deposits; $10=$ dolomite; $11=$ evaporite; $12=$ glauconite; 13 = coal; $14=$ volcanic rocks; and $15=$ plutonic rocks. For key to letters, see Figure 1 . 
On the East Qangtang block ( $\left.\mathrm{s}^{\prime \prime}\right)$, the late Permian sedimentation was predominantly of marginal marine to shelf and was represented mainly by carbonaceous shales intercalated with fossiliferous calcareous sandstones, dark gray, thinly bedded limestones, coal deposits, basalts, andesites, and trachyandesites (Pearce and Mei, 1988). The lava flows overlie Maukouan-age sedimentary rocks. (The Maukouan is considered by Chinese stratigraphers the equivalent of the Ufimian and Kazanian (Zhang, 1984). Haq and Van Eysinga (1987) consider the Maukouan more or less equivalent to the Kazanian.) They contain common brachiopods, bivalves, and plant remains (Jixiang et al., 1988).

Unlike the Qangtang block, the North China block (q) was mainly a depositional land where fluvio-lacustrine variegated and locally tuffaceous sandstones and shales with minor amounts of conglomerates, marls, and limestones were deposited (Fig. 4) (Lexique, 1963, 1971).

Besides the land and/or erosional areas of the Jiangnan Plain (Zhang, 1984), the late Permian sedimentation on the Yangtze block $(w)$ was mainly represented by marginal marine to shelf carbonates and associated fine-grained clastic rocks (Figs. 4 and 5) (Ting and Grabau, 1934; Lexique, 1963, 1971; Jixiang et al., 1988). On the Shaluli Shan island-arc (u) which formed, probably together with the East Qangtang block $\left(\mathrm{s}^{\prime \prime}\right)$, a narrow tail of the Yangtze block (w) (Fig. 5) during this period, these sediments were intercalated with basaltic and andesitic volcanic rocks (Jixiang et al., 1988). The marginal marine sediments accumulated in the vicinity of the KangDian Mountains and Jiangnan Plain and consist of yellow, gray, green, and black carbonaceous shales, sandy shales, and sandstones with coal beds and basalts in part. In the shelf areas of the Yangtze block (w), micritic limestones rich in benthic organisms, such as fusulinids, brachiopods, and bivalves, were laid down (Fig. 4) (Yang et al., 1981). The southern parts of the Yangtze block (w) witnessed in the late Permian the widespread Emei Shan basalt eruptions (Lin and Fuller, 1990). We hypothesize that this episode of "withinplate" volcanism was coeval and cogenetic with the late Permian basalts on the eastern Qangtang block $\left(\mathrm{s}^{\prime \prime}\right)$ and likely occurred behind the juvenile Shaluli Shan arc (u), similar to the Cenozoic Patagonian plateau basalts behind the southern Andean Cordillera in South America (Baker et al. 1981).

The eastern part of the Huanan block (y) was in the late Permian an erosional land area (Fig. 4) (Zhang, 1984) with local continental deposition characterized by coal-bearing sandstones and shales. Westward (i.e., oceanward, Fig. 5) from the land, marginal marine, shelf, and continental slope sediments accumulated. Marginal marine sediments consist of alternating continental to marine clastic rocks and carbonates with local coal deposits. Along the western continental margin of the Huanan block (y), deep-water siliceous mudstones and limestones containing abundant ammonoids, pectens, and small brachiopods were deposited (Lexique, 1971; Zhang, 1984).

The late Permian sediments on the Annamia block (x) appear to be limited in areal extent. In the major parts of this block, the sediments of this age do not exist, indicating that the Annamia block ( $\mathrm{x}$ ) was largely a land and/or erosional area during the late Permian similar to eastern Huanan (y) (Fig. 4). In the southern part of this block, shelf conditions existed under which limestones, marls, and shales containing benthic foraminifers such as paleofusulinids were deposited. In northern Vietnam, shelf areas received sandstones, shales, siliceous shales, and siliceous limestones with bauxite horizons. In western Bacbo, Vietnam, these deposits were intercalated with widespread basalts (Khuc et al., 1986). On the western part of the Annamia block (x) (i.e., in northeastern Thailand) the shelf areas were mostly covered with carbonate grainstones and packstones with late Permian fusulinids. In the marginal marine areas of this region, alternation of shales, siltstones, cross-laminated sandstones, and thin limestones accumulated. Here, the shelf deposits were replaced oceanward by a deep-water sedimentary assemblage comprising black to gray shales, cherts, gray and graded allodapic limestones, and siliciclastic turbidites with volcaniclastic rocks (Winkel et al., 1983; Wielchowsky and Young, 1985).

Except for the land or erosional region located in the eastern part of the Central Pamir/West Qangtang ( $\left.s^{\prime}\right)$, all of the Central Pamir-Qangtang-Sibumasu block (s) was a carbonate platform during the late Permian. In the western Central Pamir/West Qangtang ( $\left.\mathrm{s}^{\prime}\right)$, limestones, siliceous limestones, and marls with siliceous shales, cherts, and volcanic rocks (basalts and tuffs) were deposited on this platform (Shvolman, 1978; Norin, 1979; Desio, 1979). On the Sibumasu block (s'"), the carbonate platform was generally poor in terrigenous sediments and dominated by limestones and dolomites. In peninsular Malaysia and northwestern Sumatra these carbonates were intercalated with volcanic rocks (Bunopas, 1981; 1983; Metcalfe, 1988).

The Gondwanian margin of the Paleo-Tethys ocean east of the Pamirs was constituted in the late Permian by the Helmand block, India, and Australia, to which the smaller continental fragments of Sikuleh $\left(z^{\prime}\right)-N a t a l ~\left(z^{\prime \prime}\right)$ and Lhasa-Central Burma (5t) were then still attached (Fig. 5). Major parts of peninsular India formed land with the local deposition of coal-bearing clastic rocks in the eastern part (Datta et al., 1983; Roybarman, 1983). On the northern Indian margin (i.e., on the Tethys Himalayas and the Lhasa-Central Burma block (t), a shelf environment existed. On this shelf, carbonates and associated clastic rocks were deposited (Gannser, 1964; Desio, 1979; Jain, 1981). This shelf was disrupted mainly along the west Lhasa-south Pamir block by a deep-marine trough where dark-colored to black Productus- and ammonite-bearing shales, siliceous shales, and limestones were deposited (Figs. 4 and 5). South of this area, the Panjal trap volcanism was active (Gansser, 1964; Fuchs, 1982; Sastry et al., 1984; Gaetani et al., 1986). On the Nagqu ( $\left.\mathrm{t}^{\prime \prime}\right)$ and Lhasa proper sub-blocks $\left(\mathrm{t}^{\prime \prime \prime}\right)$, the depositional area was an inner shelf in character where marginal marine dark green, gray, and black shales, sandy shales, sandstones conglomerates, and limestones with local volcanic rocks and coal deposits accumulated (Lexique, 1963; Gansser, 1964; Jixiang et al., 1988). Toward Central Burma and Mount Victoria Land, which formed the northern part of the northwestern Australian margin during this time, they passed into shelf carbonates consisting of bioclastic limestones and dolomites (Mitchell et al., 1977). The late Permian sediments on the present northwestern Australian margin appear to be very similar to those of the Lhasa-Central Burma block $(t)$. They occur on land in the Bonaparte, Canning, and Carnarvon basins, all forming parts of the Westralian super basin (Yeates et al., 1986; Mory, 1988; Hocking, 1988; Gunn, 1988; Horstman and Purcell, 1988; Bradshaw et al., 1988). They are also found in several offshore wells, and seismic evidence suggests that they are present under much of the northwest continental shelf (e.g., Yeates et al., 1986, fig. 5). They consist of carbonates and clastic rocks with minor coal deposited in an environment ranging from land to shelf. Depositional environment was mainly a shelf in the Carnarvon Basin with marginal marine environment inshore (Figs. 4 and 5) (Hocking, 1988). In the Bonaparte Basin a large deltaic complex developed from the south which was then transgressed and overlain by progradational marginal marine sediments (barrier bar and lagoonal sediments) (Bhatia et al., 1984; Bradshaw et al., 1988; Mory, 
1988; Gunn, 1988). Toward the northwest, shelf carbonates and associated shales were deposited on the Ashmore and Sahul platforms, indicating an increase in marine influence in this direction (Powell, 1976; Veevers, 1984; Mory, 1988; Gunn, 1988). However, the sea in these northwestern areas, though still linked to the main part of the Banggong Co-Nu Jiang ocean, was restricted in overall extent (Yeates et al., 1986) because the Sikuleh-Natal fragment (z) formed a land barrier (Cameron et al., 1980) between the carbonate shelf on Mount Victoria Land to the north and the Ashmore-Sahul carbonate platform to the south (Fig. 5), restricting the latest Paleozoic-earliest Mesozoic environments in the Westralian superbasin.

\section{Late Triassic (Norian-Rhaetian: Figs. 6 and 7)}

By the Late Triassic, the North China block (q) had already been welded firmly onto the eastern appendage of the main Laurasian continent along the Suolun-Xilamulun (XVI) and Inner Mongolian (XV) sutures (Fig. 7). The Laurasian margin east of the Pamirs was during this time a continental area with local fluvio-lacustrine sedimentation taking place on parts of the North China (q), Alxa (p), and Qaidam (o) blocks to the north of the Songpan-Ganzi region (Fig. 6). The fluviolacustrine sediments in these areas are represented mainly by coal-bearing red, yellow, and gray sandstones, siltstones, shales, sandy shales, and argillaceous limestones (Rukhin, 1960; Lexique, 1963, 1971; Wang, 1985). Marine sedimentation was restricted only to the areas close to the Hoh Xil Shan/Jinsha Jiang ocean (XXI). Today, marginal marine and shelf deposits of the Late Triassic age crop out along the suture zone of this ocean (XXI). Marginal marine sediments are found in the southwestern Kuen-Lun, southern Serindia, and southern Songpan-Ganzi region and consist of gray to black carbonaceous shales, sandstones, and conglomerates with coal intercalations (Fig. 6) (Lexique, 1963, 1971; Wang, 1985; Yang, 1986; Molnar et al., 1987; Chang et al., 1989).

The other continental blocks that existed in the late Permian docked during the Late Triassic to Laurasia as the Paleo-Tethys ocean was closing (Fig. 7) with the exception of the Helmand-South Pamir-Lhasa block (t). The Late Triassic sediments on the Yangtze block (w) were mainly of marginal marine and characterized by black shales, sandstones, and conglomerates with plant remains and coal beds. They were replaced by continental red beds where land areas existed on this block during the Late Triassic, corroborating the view that it had collided by this time with Laurasia (Fontaine and Workman, 1978; Khuc, 1986; Hutchison, 1989b).

The Huanan block (y) was in large part characterized by erosional and continental depositional areas in the Late Triassic (Fig. 6). However, marginal marine areas also existed in the south. Red beds, brown to black shales, sandy shales, and sandstones with coal intercalations and plant remains accumulated on the lowlands. In the marginal marine region, conglomerates, sandstones, and shales with local coal beds were deposited (Fig. 6) (Lexique, 1963, 1971; Fontaine and Workman, 1978; Hutchison, 1989b).

The late Permian erosional areas on the Annamia block (x) were during the Late Triassic largely converted to continental and marine depositional realms (Figs. 6 and 7). Fluvio-lacustrine plant-bearing clastic rocks and red beds accumulated mainly on the Khorat Plateau (Workman, 1977; Fontaine and Workman, 1978; Bunopas, 1981; Hutchison, 1989b). Similar rocks were laid down in the northern part of the Chola Shan (v). Elsewhere on Annamia marine sediments were predominant. They were mostly of marginal marine and characterized by dark-colored shales and siltstones with plant remains, coal deposits, and marine fossils. Toward the north and east they passed in part into coral- and brachiopod-bearing shelf limestones and associated clastic rocks (Fig. 6) (Fontaine and Workman, 1978; Hahn, 1982; Hutchison, 1989b).

The Late Triassic sedimentation on the Central PamirQangtang-Sibumasu (s) block was generally marginal marine and shelf (Figs. 6 and 7). Marginal marine sediments commonly accumulated on the Central Pamir/West Qangtang $\left(\mathrm{s}^{\prime}\right)$ and East Qangtang $\left(s^{\prime \prime}\right)$ blocks and were represented by interbedded sandstones, shales, and limestones with volcanic rocks in part. Similar sediments were also deposited on the eastern part of the Sibumasu block and in peninsular Malaysia (Workman, 1977; Bignell and Snelling, 1977; Rajah and Yin, 1980; Fontaine and Workman, 1978; Bunopas, 1981; Wang et al., 1981; Chang et al., 1989; Hutchison, 1989b). Elsewhere on this block, shelf deposits comprising limestones with subordinate dolomites and clastic rocks accumulated (Norin, 1976; Rajah and Yin, 1980; Desio, 1979; Bunopas, 1981; Bender, 1983; Casnedi and Nicora, 1985; Hutchison, 1989b).

Major parts of the Lhasa-Central Burma block (t), newly rifted from Gondwana-Land, were occupied during the Late Triassic by a landmass extending now between Burma and the western Lhasa-south Pamir region along the Mandalay (XL) and Banggong Co-Nu Jiang (XXIV) suture zones (Figs. 6 and 7) (Jixiang et al., 1988; Wang, 1985). On this land, continental clastic rocks with andesitic volcanic intercalations occurred in the southern Tibet autonomous region (Chang et al., 1989). Outside the land area, marine conditions prevailed on this continental block. Marine sediments were mainly deep-marine turbidites in Burma (including the Mount Victoria Land) and coral- and megalodont-bearing shelf carbonates and dolomites with associated clastic rocks in Lhasa, southern Pamir, and Ladakh regions (Fig. 6) (Casnedi and Mosna, 1979; Tapponnier et al., 1981; Baud et al., 1982; Searle, 1983; Fuchs, 1982, 1987; Reynolds et al., 1983; Bhalla, 1983; Gaetani et al., 1985, 1986; Casnedi and Nicora, 1985).

The presence of Triassic andesites on the Lhasa block may be indicative of subduction. If such subduction existed it must have been located on the present northern and eastern side of the Lhasa-Central Burma block and dipped toward the block, because its southern side had only just formed in the Early Triassic and carries no record of subduction until the Late Jurassic.

As the Lhasa-Central Burma block (t) was rifted during the Late Triassic off Gondwana-Land (as a migratory arc?), resulting in the opening of the Neo-Tethys east of the Pamirs, the Gondwanian margin in this region was represented by northern India and northwestern Australia (Fig. 7). The latter included during this time the small Sikuleh-Natal (z) continental fragment, including its possible westerly extension in northwest Java. Major parts of peninsular India constituted in the Late Triassic a land area with continental deposits in the Bengal, Bihar, and Madhya Pradesh regions. The continental deposits are commonly red conglomerates, sandstones, and shales with plant fossils in part. Toward the Tethys Himalayas, they pass into mainly latest Triassic shelf deposits characterized predominantly by oolitic and bioclastic carbonates generally interbedded with fine-grained clastic rocks (Fig. 6) (Bordet et al., 1972; Anonymous, 1980; Stöcklin, 1980; Wang et al., 1981; Tiwari et al., 1984; Valdiya, 1983; Gaetani and Garzanti, 1989, in press). Along the Indus/Yarlung-Zangbo suture zone (31), the shelf deposits are locally replaced by turbidites (Wang et al., 1981; Yin et al., 1983).

The Late Triassic sediments on the northwestern Australian margin are predominantly nonmarine, although marine carbonates with associated marginal marine clastic rocks are found on the Wombat Plateau and Ashmore and Scott reefs (Figs. 6 and 7) (Barber, 1988; Leg 122 Shipboard Scientific 


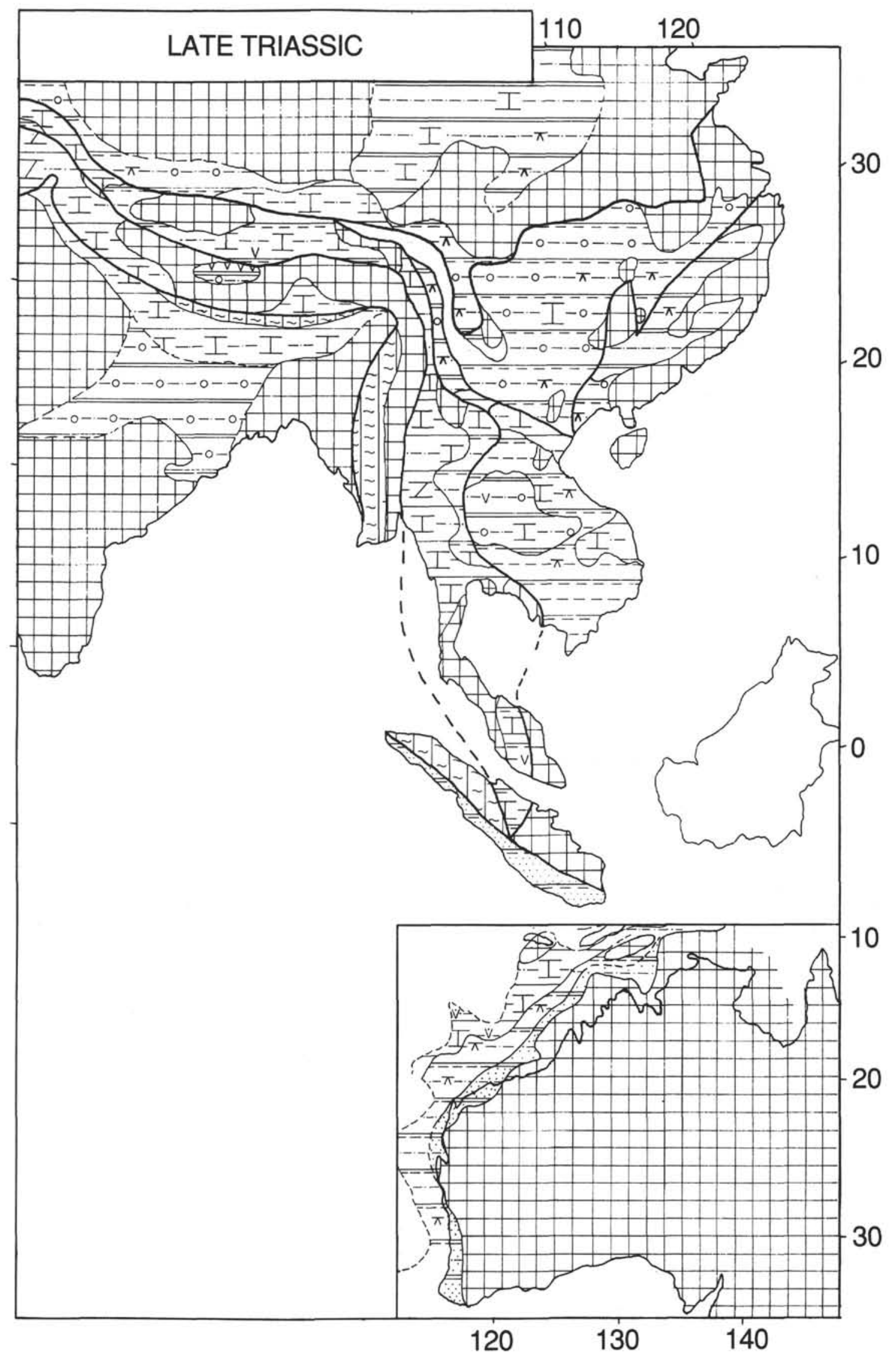

Figure 6. Non-palinspastic Late Triassic paleogeographic map of the eastern Tethys (main sources from which this map was compiled are cited in text). For legend see Figure 4. 


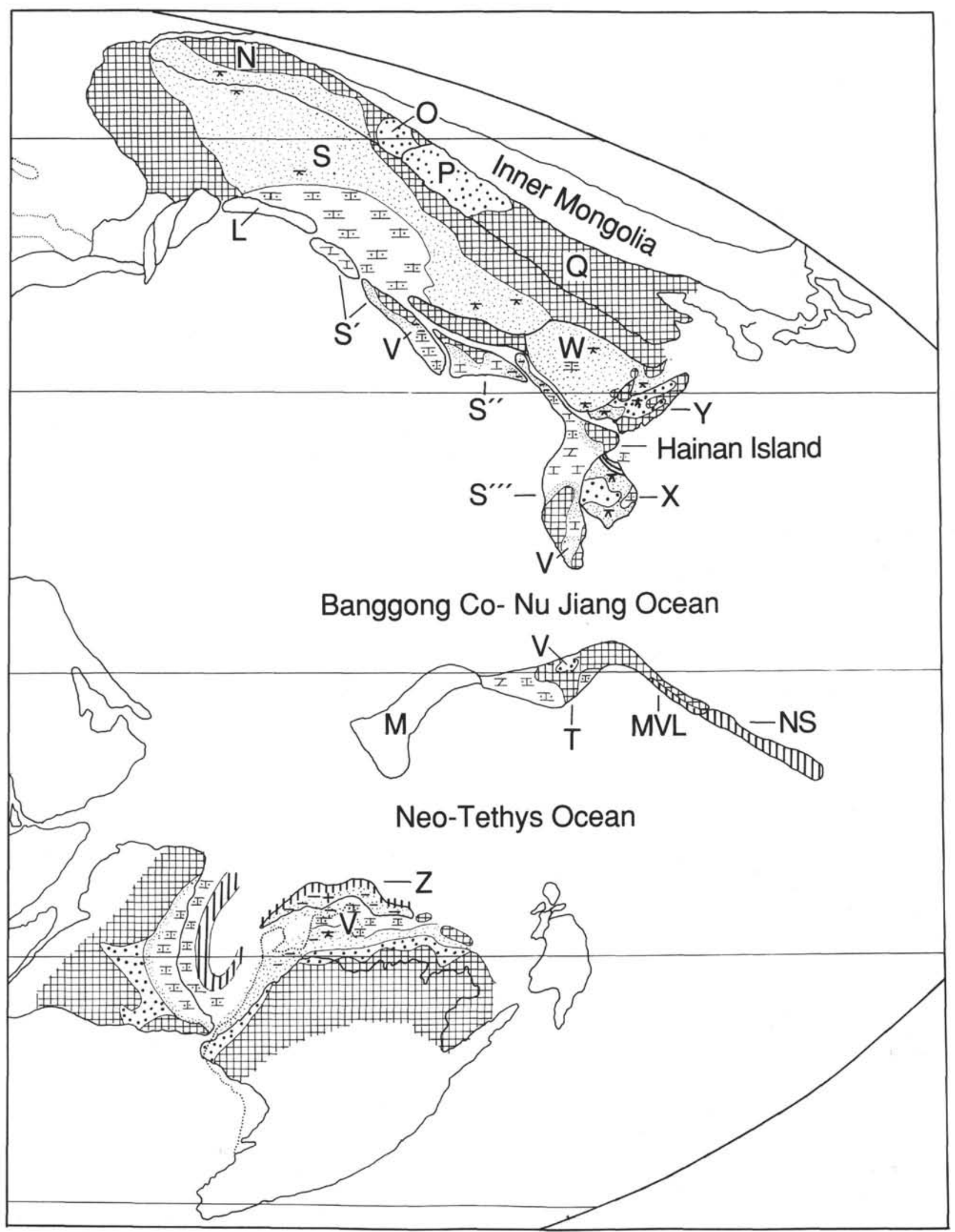

Figure 7. Late Triassic paleotectonic sketch map of the eastern Tethys. (Distribution of the main continents is taken from Scotese et al., 1987). For legend see Figure 5. 
Party, 1989). They show a zonal arrangement of nonmarine, marginal marine, and shelf environments in a northwesterly direction toward the Tethyan region (Fig. 6). These sediments are locally intercalated with rhyolitic and trachytic volcanic rocks (von Rad and Exon, 1983; Yeates et al., 1986) consistent with the ongoing extensional tectonism at this time. Continental sediments consist of sandstones and shales with coal intercalations. Shelf carbonates are characterized by white, pale brown, pink, and red alternating boundstone, grainstone, and dolomitic claystone (Leg 122 Shipboard Scientific Party, 1988; von Rad et al., 1989). Marginal marine sediments are represented by sandstone and siltstone with coal deposits in part (Crostella and Barter, 1980; Exon et al., 1982; Yeates et al., 1986; Bradshaw et al., 1988; Hocking, 1988; Parry and Smith, 1988; Gunn, 1988; von Rad et al., 1989). On the Sikuleh-Natal fragment (z) marginal marine to shallow-marine sandstones were deposited possibly during this time (inferred from data in Cameron et al., 1980). Farther north, these sediments were replaced by continental margin sediments consisting of limestones, marly shales, siliceous shales, and radiolarian cherts (van Bemmelen, 1949; Audley-Charles, 1978; Cameron et al., 1980). K-Ar ages on biotites suggest that biotite granites were being intruded into the Sikuleh-Natal fragment $(z)$ in the latest Triassic, which might be due to the coeval (south-dipping) subduction here (D. E. Karig, pers. comm., 1985). Data from wells located east and northeast of the Scott Plateau (Scott Reef No. 1, North Hibernia No. 1, and Ashmore Reef No. 1) indicate a west to northwest sediment source during the Triassic (Powell, 1976). It is suggested here that this source was most probably the Sikuleh-Natal continental arc fragment (z) (Fig. 7).

\section{Late Jurassic (Kimmeridgian-Tithonian: Figs. 8 and 9)}

By the Late Jurassic, the Yangtze (w), Huanan (y), Annamia (x), and Central Pamir-Qangtang-Sibumasu blocks (s) all had been accreted to Laurasia. The Laurasian continent therefore grew southward in lateral extent and the newly accreted areas became mainly the site of continental deposition (Figs. 8 and 9). Marine sedimentation was mainly restricted to parts of the previously independent Central Pamir-Qangtang-Sibumasu block (s). Major parts of Laurasia east of the Pamirs were erosional lands on which continental basins of various size developed on the Tarim, Qaidam (o), Alxa (p), North China (q), Yangtze (w), Huanan (y), Annamia (x), and eastern part of the Sibumasu $\left(\mathrm{s}^{\prime \prime \prime}\right)$ blocks (Figs. 8 and 9). Black, gray, and red shales, graygreen sandstones, and sandy conglomerates with coal intercalations were laid down in the basins developed on the Qaidam block (o) (Lexique, 1963, 1971). In the Alxa (p) basins, the continental deposits are represented mainly by red beds consisting of red shales, sandy shales, micaceous sandstones, and conglomerates with minor amounts of coal deposits (Fig. 8) (Lexique, 1963, 1971; Xu et al., 1989). The continental basins on the North China block (q) contain mainly alternation of red clastic rocks in the west (i.e., in the Ordos basin, Sun et al., 1989) and red clastics and coal-bearing black carbonaceous shales with acidic and basic volcanic rock intercalations in the east (i.e., in the Hubei-Bohai Gulf basin) (Fig. 8) (Lexique, 1963, 1971; Hu et al., 1989). The basins on the Yangtze block $(w)$ have infill characterized mainly by red sandstones, shales, and conglomerates in part with coal deposits and evaporites (Lexique, 1963, 1971; Hutchison, 1989b; Zhang et al., 1989). In the east (i.e., in the Subei-Yellow Sea basin), these deposits contain common intermediate and acidic volcanic rocks. On the Huanan block (y) continental basins are found along the Pacific Ocean and contain alternation of clastic rocks and volcanic rocks such as trachyandes- ite, trachyte, andesite, rhyolite, granodiorite, and tuffs (Fig. 8) (Lexique, 1963, 1971).

On the Annamia (x) and the eastern part of the Sibumasu $\left(\mathrm{s}^{\prime \prime \prime}\right)$ blocks the continental deposits consist mainly of red beds with local evaporites and volcanic rocks (Ridd, 1978; Bunopas, 1981; Fontaine and Workman, 1978; Hutchison, 1989b). They pass westward into shelf carbonates in western Thailand (Fig. 8) (Bunopas, 1981; Hutchison, 1989b). Another region of marine deposition was the Central Pamir and Qangtang (s) areas where yellow, gray to black sandstones, shales, and siltstones with coal and bivalve fossils were deposited in a marginal marine environment (Fig. 8) (Lexique, 1963, 1971; Jixiang et al., 1988).

During the Late Jurassic, on the Lhasa-Central Burma block $(t)$ marine conditions prevailed mostly on the Bongthol Tangla $\left(\mathrm{t}^{\prime}\right)$, Nagqu $\left(\mathrm{t}^{\prime \prime}\right)$, Lhasa proper $\left(\mathrm{t}^{\prime \prime \prime}\right)$, Ladakh $\left(\mathrm{t}^{\prime \prime \prime}\right)$, and west Lhasa-south Pamir $\left(\mathrm{t}^{m{ }^{\prime \prime \prime}}\right)$ blocks (Fig. 8). Central Burma and Mount Victoria Land were mainly land areas during this period (Bender, 1983). The western part of the Bongthol Tangla $\left(\mathrm{t}^{\prime}\right)$, west Lhasa-south Pamir blocks $\left(\mathrm{t}^{\prime \prime \prime \prime}\right)$, and Ladakh $\left(\mathrm{t}^{\prime \prime \prime \prime}\right)$ were the depositional sites for deep-water, thinly bedded, carbonaceous black shales and limestones with common ammonites and belemnites (Lexique, 1963, 1971; Gansser, 1964; Wadia, 1966).

The Gondwanian margin was constituted during the Late Jurassic by India and northwestern Australia with the SikulehNatal continental fragment $\left(z^{\prime}+z^{\prime \prime}\right)$ still attached to Australia during this period (Fig. 9). Peninsular India was generally an erosional land, and deep-water sediments similar to those on the western Bongthol Tangla $\left(\mathrm{t}^{\prime}\right)$, west Lhasa-south Pamir $\left(\mathrm{t}^{\prime \prime \prime \prime}\right)$, and Ladakh $\left(\mathrm{t}^{\prime \prime \prime \prime}\right)$ blocks accumulated on its northern margin (Gansser, 1964; Wadia, 1966).

In the Late Jurassic, on the major parts of the northwestern Australian margin, thick marine shales and siltstones with minor limestones and marls were deposited (Fig. 8). A coarser-grained fringe of marginal marine to fluvial deposits rims the landward part of the Northwest Shelf region. Volcanic rocks were intercalated with these sediments in the Browse Basin and Ashmore platform (Powell, 1976; Exon and Wilcox, 1978; Bradshaw et al., 1988; Barber, 1988; Willis, 1988). Although most of these marine sediments accumulated on a shelf environment, there were some extensional deep-marine troughs (i.e., Barrow sub-basin, Vulcan sub-basin, Malita Graben, and Sahul Depression) disrupting the shelf and receiving siliciclastic turbidites (Hocking et al., 1987; Bradshaw et al., 1988). Parts of Ranking Platform, Browse Basin, and Ashmore Platform were land during the Late Jurassic. The rapid deepening in the Late Jurassic of the Barrow Basin, Vulcan sub-basin, Malita Graben, and Shaul Depression may have been related to the latest Jurassic-Early Cretaceous rifting of the Sikuleh-Natal continental fragment $\left(z^{\prime}+z^{\prime \prime}\right)$ from Australia. During this time, this fragment was the depositional site for the shallow-water carbonates and clastic rocks with tuffs in part (Yancey and Alif, 1977).

\section{Early Cretaceous (Aptian-Albian: Figs. 10 and 11)}

After the Early Cretaceous collision of the Lhasa-Central Burma block ( $\mathrm{t}$ ) along the Banggong Co-Nu Jiang (XXIV) and Mandalay (XL) sutures with the Central Pamir-QangtangSibumasu (s) block, all the Tethyside continental units east of the Pamirs except the Sikuleh-Natal $\left(z^{\prime}+z^{\prime \prime}\right)$ fragment constituted the Laurasian southern continental margin (Figs. 10 and 11). By the Aptian-Albian, land areas and continental basins were widespread in northern Tibet, China, and Indochina (Fig. 10). In China, continental deposits are found in various basins, such as Tarim, Qaidam, Ordos, Sichuan, Southeast China, Heng-Yang, East China Sea, Subei-Yellow 


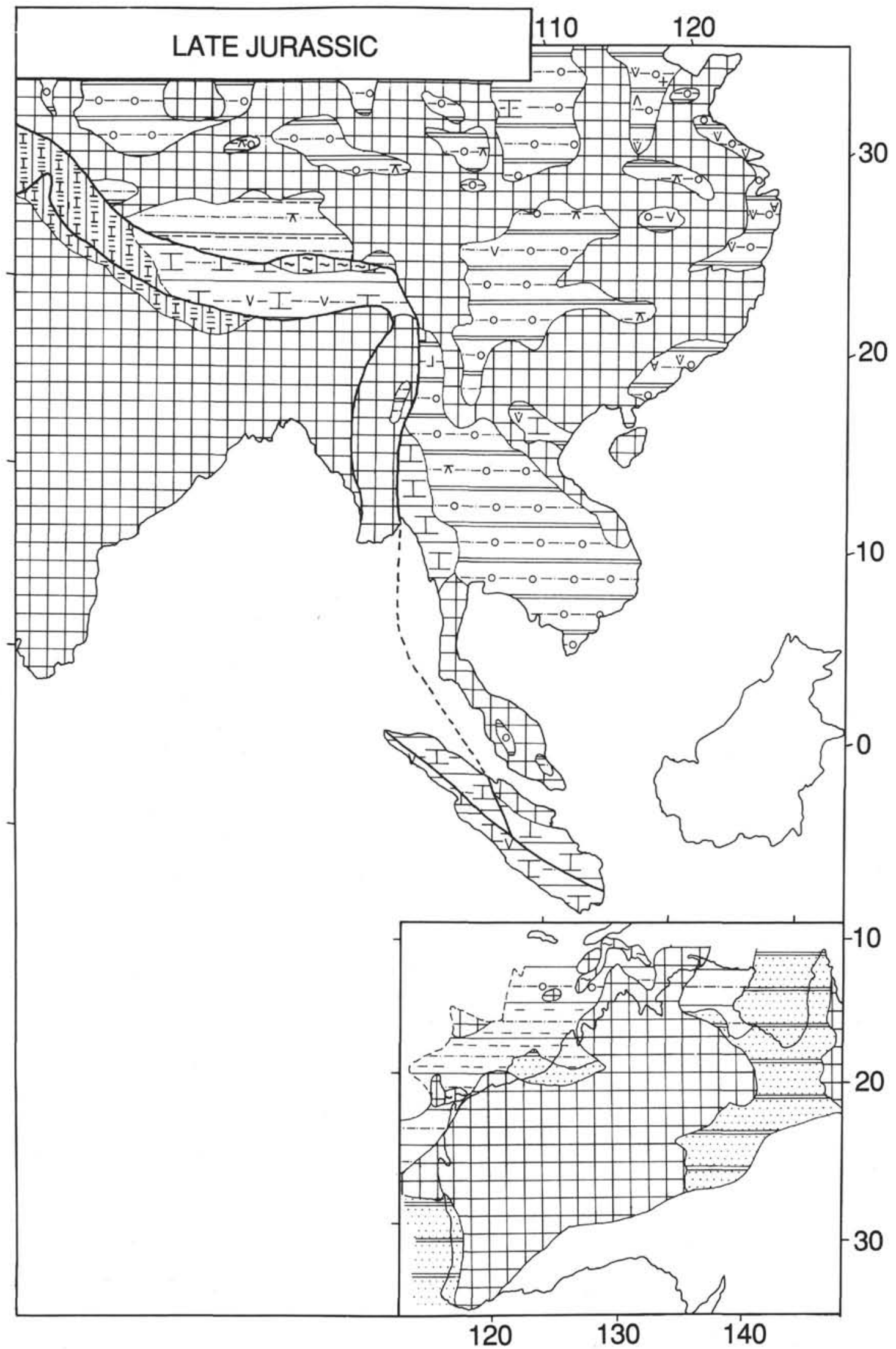

Figure 8. Non-palinspastic Late Jurassic paleogeographic map of the eastern Tethys (main sources from which this map was compiled are cited in text). For legend see Figure 4. 


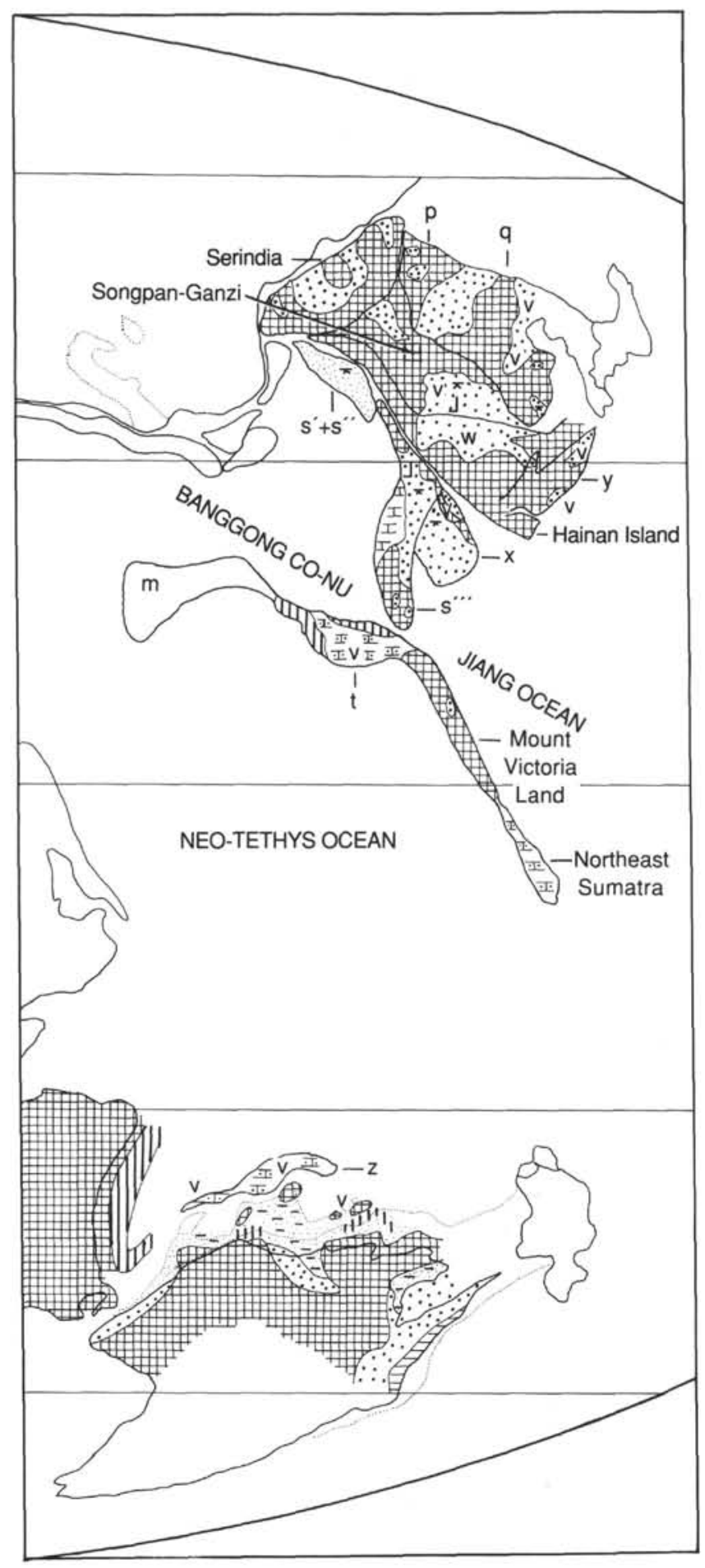

Figure 9. Late Jurassic paleotectonic sketch map of the eastern Tethys. (Distribution of the main continents is taken from Scotese et al., 1987). For legend see Figures 1 and 5.

Sea, and Hubei-Bohai Gulf basins (Jia et al., 1985; Shicong et al., 1985; Longyun, 1985; Cheng, 1985; Jiongkun et al., 1985; Jiazhen, 1985) (Fig. 10). In most of these basins, the sediments are generally several hundreds to thousands of meters thick and are represented mainly by interfingering red alluvial clastics and mottled lacustrine rocks. Locally they contain evaporites and volcanic rocks. The latter are particularly abundant in the north-south-trending eastern basins (i.e., Hubei-Bohai Gulf, Subei-Yellow Sea, East China Sea, and Heng-Yang basins) (Fig. 10) (Jiazhen, 1985; Yichin et al., 1986).

In addition to China, major sites of continental deposition are found in Thailand and Vietnam (Fig. 10). Thailand was largely transformed after the Jurassic into a landmass where 400-m-thick Mesozoic sediments were deposited in three major basins, the Khorat-Phayoo, Eastern, and Southern basins (Fig. 10). In these basins, the Aptian-Albian sediments constitute the Phu Phan Formation of the Khorat Group of the Norian to early Tertiary. In the Khorat Basin, these sediments consist mainly of 80 - to 20 -m-thick, massive, cross-bedded, medium- to coarse-grained, often conglomeratic sandstones with common middle Cretaceous fauna (Kobayashi, 1968; Pitakpaivan and Chonglakmani, 1978).

During the Aptian-Albian, the Neo-Tethys sea extended only as far north as into Tibet (Henning, 1915; Douvillé, 1915; Chen, 1986) and deposited on the Lhasa-Central Burma block (t) 500 - to $1000-\mathrm{m}$-thick, poorly bedded $\mathrm{Orbi}$ tolina limestones with minor shales and volcanic rocks (mainly rhyolite and ignimbrite) in part (Fig. 10) (Marcoux et al., 1987). On the northern domain of Lhasa proper $\left(\mathrm{t}^{\prime \prime \prime}\right)$, these deposits are intercalated with tuffaceous clastic rocks and become more marginal marine upward (Naiwan et al., 1981; Burg, et al., 1983). These shelf deposits form a narrow belt on the northern side of the Indus/Yarlung-Zangbo suture, extending from Burma to Afghanistan. In the Chindwin district of Burma, they occur in similar facies represented by Orbitolina limestones with minor amounts of calcareous shales and sandstones (Brunnschweiler, 1966). To the south of Lhasa proper $\left(\mathrm{t}^{\prime \prime \prime}\right)$, the shelf deposits are replaced along the Indus/Yarlung-Zangbo suture zone by thick turbidites with siliceous-shaley sequences with radiolarites and pelagic limestones passing into oceanic volcanic and volcaniclastic facies (Fig. 10) (Bordet et al., 1971; Gansser, 1980; Marcoux, et al., 1982).

By the Aptian-Albian, India and Sikuleh-Natal $\left(z^{\prime}+z^{\prime \prime}\right)$ had been newly rifted off Australia, resulting in the opening of the Indian Ocean (Fig. 11). Land and/or erosional areas constituted major parts of peninsular India. On its eastern side, marginal marine sediments occur in the Bengal and Athgarh basins (Fig. 10). In both basins, these sediments are represented mainly by sandstones and shales with lesser amounts of conglomerates and limestones (Rahman, 1963; Datta et al., 1983). In the Rajmahal Hills, west of the Bengal basin, a correlative thick tholeiitic basalt is observed (Datta et al., 1983). These volcanic rocks were manifestations of the opening of this sector of the Indian Ocean. During the evolution of this ocean, a triple junction of rift arms formed in the easternmost part of Gondwana-Land. The Althgarh basin constituted one of these rift arms with its Aptian-Albian shallow-marine to nearshore sedimentary infill. The distension of the crust accompanying the fragmentation of the Indian plate was represented by an outpouring of tholeiitic basalts in the Rajmahal Hills (Rao and Mitra, 1978; Datta et al., 1983).

Shelf sediments on the northern Indian margin crop out along the Indus/Yarlung-Zangbo suture zone (Fig. 10). They consist of glauconitic sandstones, shales, and Orbitolinabearing marls and limestones (Remy, 1975; Fuchs, 1979; Anonymous, 1980; Searle, 1983). Glauconitic sandstones and shales are widespread in the Spiti and Kumaun regions. In the Ladakh area of Kashmir, carbonates are mainly oolitic in texture (Bhalla, 1983). The Albian Giumal sandstone in the Tethyan Himalayas contains abundant volcanic detritus and basaltic lava flows, indicating the presence of an extensional event (Gaetani and Garzanti, 1989, in press). 


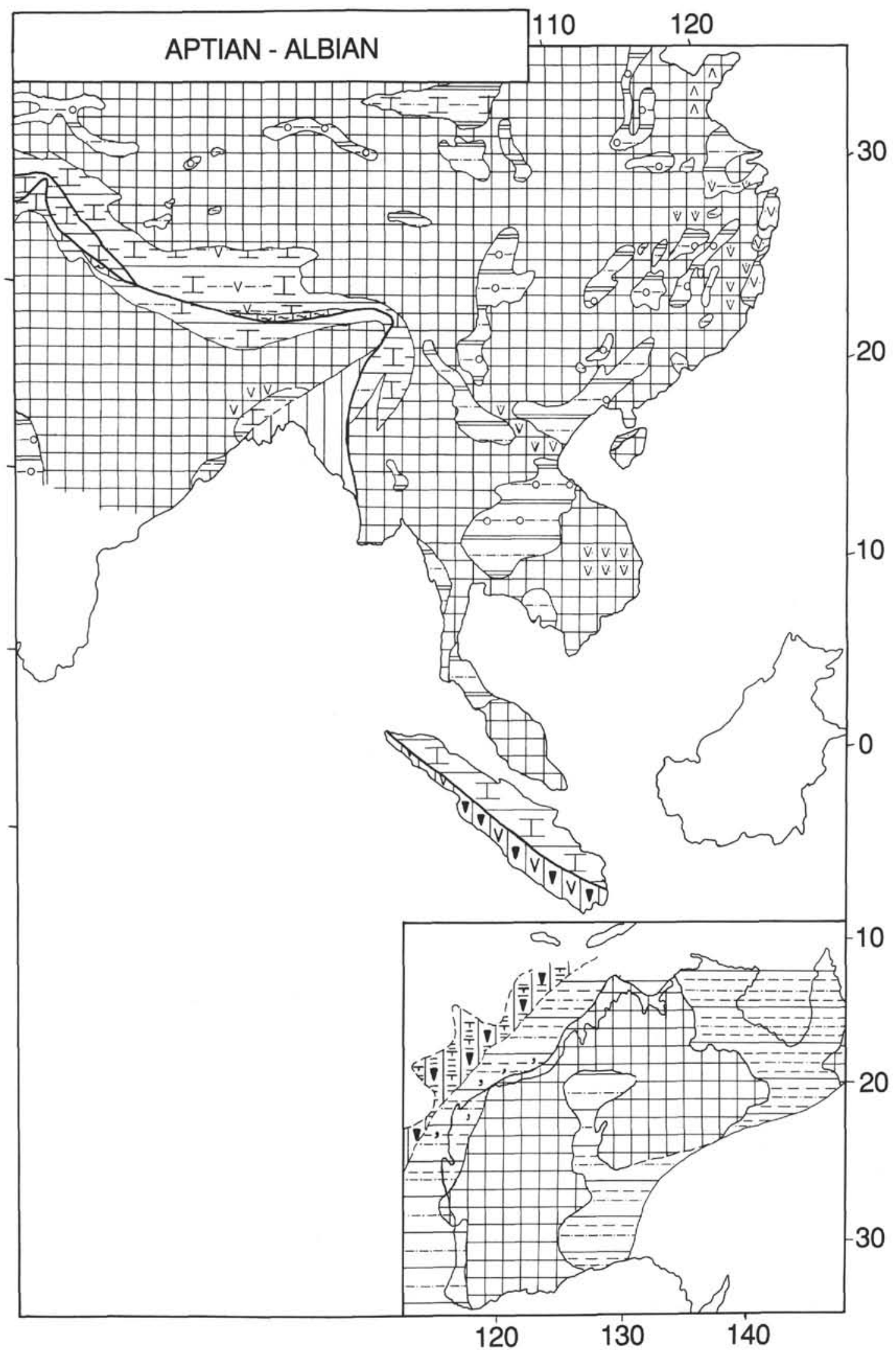

Figure 10. Non-palinspastic Aptian-Albian paleogeographic map of the eastern Tethys (main sources from which this map was compiled are cited in text). For legend see Figure 4. 


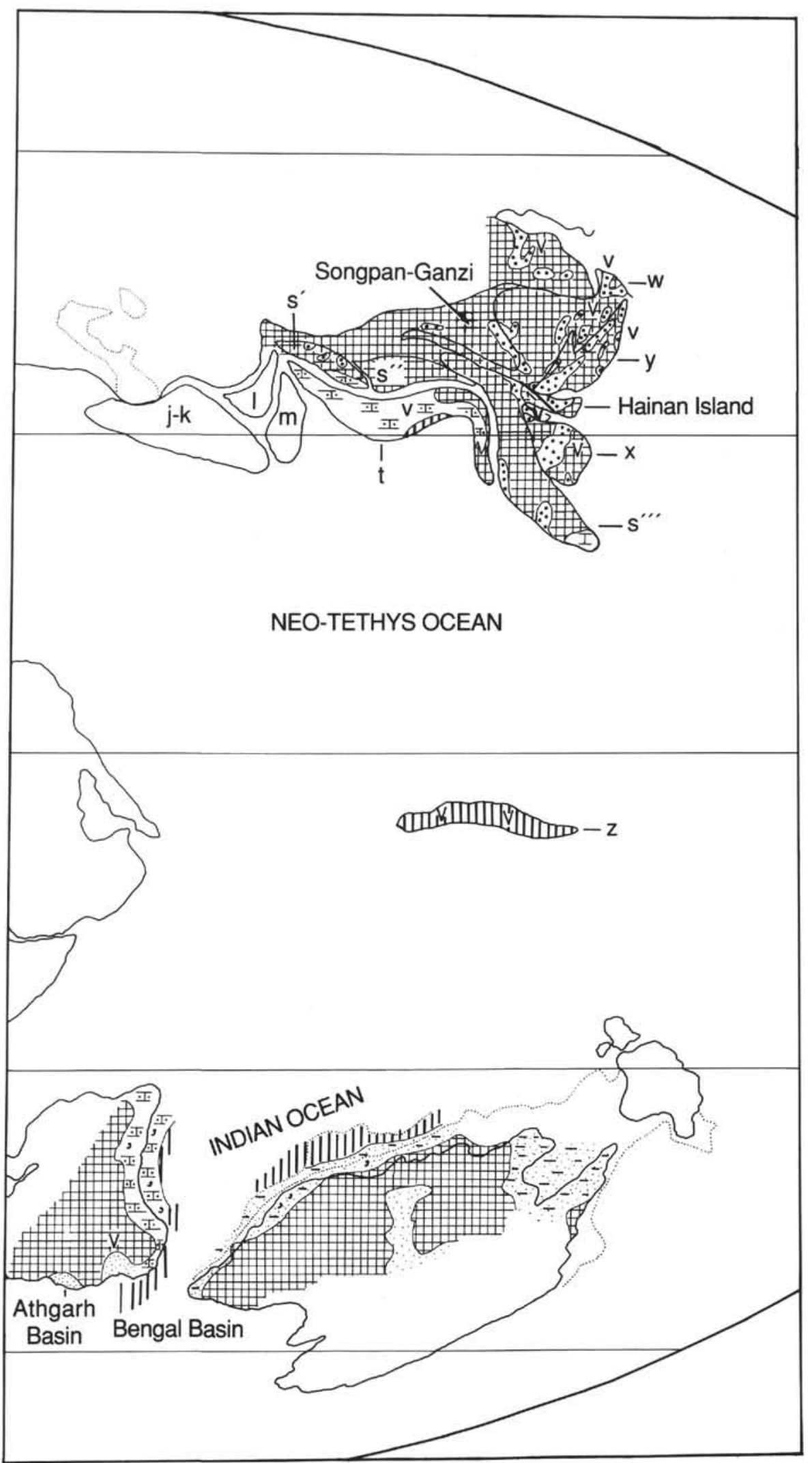

Figure 11. Aptian-Albian paleotectonic sketch map of the eastern Tethys. (Distribution of the main continents is taken from Scotese et al., 1987). For legend see Figures 1 and 5. 
Table 1. Comparison of times of suturing in the Asiatic Tethysides with times of rifting along the northwest Australian margin.

\begin{tabular}{|c|c|c|c|c|}
\hline SUTURE & $\begin{array}{l}\text { TIME } \\
\text { OF } \\
\text { CLOSURE }\end{array}$ & SUTURED & $\begin{array}{l}\text { CONSTRAINTS ON } \\
\text { DEPARTURE TIMES } \\
\text { FROM NW AUSTRALIA }\end{array}$ & $\begin{array}{l}\text { TIMES OF BREAK-UP } \\
\text { IN NW AUSTRALIA }\end{array}$ \\
\hline $\begin{array}{l}\text { xxvIII (Tamky-Phueson) } \\
\text { xxıx (Song Ma) } \\
\text { xIv (Suelun-Hegen Mountains) } \\
\text { xv (Inner Mongolian) } \\
\text { xvI (Suolun-Xilamulun) } \\
\text { xvII (Greater Khingan) } \\
\text { xxxII (Qin Ling-Dabie Shan) } \\
\text { xxxvI (Shaoxing-Pingxiang) } \\
\text { xxvII (Nan-UttarditS'a-Kaeo) } \\
\text { xxxI (Bentong-Raub) } \\
\text { xxx (Song Da) } \\
\text { xxII (Maniganggo) } \\
\text { S (Songpan-Ganzi) } \\
\text { xxIV' ('Mid-Qangtang') } \\
\text { M-O (Mongolo-Okhotsk) }\end{array}$ & $\begin{array}{l}? \in D \\
\theta C \\
C-e P \\
\pi \\
\pi \\
\pi \\
\pi \\
\pi \\
\pi \\
\pi-W \\
\text { IT-OU } \\
\text { IJ }\end{array}$ & 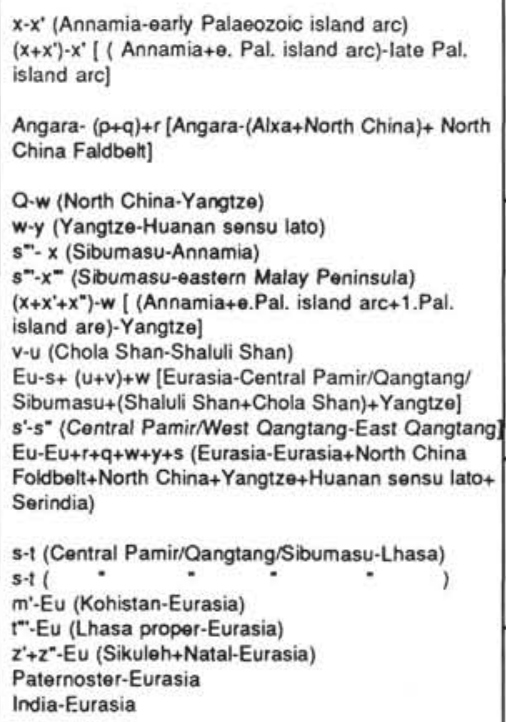 & $\begin{array}{l}\text { Blocks that could } \\
\text { not have ritted in } \\
\text { early Cretaceous or } \\
\text { later }\end{array}$ & * Mount Victoria Land ritting \\
\hline
\end{tabular}

Note: Numbers and lower-case letters identifying individual suture segments and blocks correspond to those in Figure 1. Abbreviations: $\mathrm{D}=\mathrm{Devonian}, \mathrm{C}=$ Carboniferous, $\mathrm{P}=$ Permian, $\mathrm{J}=$ Jurassic, $\mathrm{K}=$ Cretaceous, $\mathrm{T}=$ Tertiary, $\mathrm{E}=$ Eocene, $\mathrm{e}=$ early, $\mathrm{m}=$ middle, $\mathrm{I}=$ late, $\mathrm{Eu}=\mathrm{Eurasia}$, and $\mathrm{S}=\mathrm{Serindia}$. $\mathrm{A}$ hyphen $(-)$ indicates collision. A plus sign $(+)$ indicates former union by collision.

Following the breakup of the Sikuleh-Natal fragment (z) from the northwest Australian margin in the late Neocomian, this region underwent a rapid subsidence and deposited during the Aptian-Albian sandstones, dark-colored shales, clayey nannofossil ooze, nannofossil chalk, radiolarian nannochalk, and radiolarite under neritic to hemipelagic conditions (Fig. 10) (von Rad and Exon, 1983; Yeates et al., 1986; Bradshaw et al., 1988; Leg 122 Shipboard Scientific Party, 1989). These deposits document the sedimentation in the juvenile Indian Ocean (Fig. 11).

The Sikuleh-Natal fragment ( $\mathrm{z}$ ) was a depositional site for radiolarian cherts with tuffs in part during the Aptian-Albian (Yancey and Alif, 1977), indicating that the fragment subsided considerably probably under extension at this time.

\section{DISCUSSION}

In the foregoing two sections we briefly reviewed the geology and tectonic evolution of the Asiatic Tethysides with a view to constraining the possible identity of the continental objects that rifted from the northwestern margin of Australia during the final breakup leading to the establishment of the present continental margin, including the marginal Exmouth, Wombat, and Scott plateaus bordering the Gascoyne and the Argo abyssal plains. Table 1 summarizes the times of suturing in the Asiatic Tethysides and compares them with the times of rifting recorded in the Exmouth and Wombat plateaus.

First pieces of evidence for commencement of rifting was recorded by the inception of the Westralian superbasin (Yeates et al., 1986) and is dated by Veevers (1988) as late Carboniferous. We here follow S̨engör (1987), Şengör et al. (1988), Veevers (1988), and Metcalfe (1990) in identifying the Sibumasu part of Şengör's (1984) Cimmerian continent as the object that departed from northwestern Australia. The distribution of late Permian sedimentary facies both on Sibumasu and on northwestern Australia suggests that by this time ocean-floor spreading had formed a nascent ocean between the two, which formed the easterly continuation of the Banggong Co-Nu Jiang ocean in Asia.

Bunopas and Vella (1983) place a subduction zone along the present eastern margin of the Sibumasu block, although recent dating of the granites in western Malaya showed that they are all Late Triassic-Early Jurassic in age (Liew and Page, 1985; Cobbing et al., 1986). Scattered late Permian ages exist in western Thailand (see Sengör, 1986b, for a summary) and also along the strike in China. If these plutonic rocks indeed indicate the late Permian activity of a subduction zone dipping beneath the Sibumasu, this block may have detached from northern Gondwana-Land as part of an extensional arc as suggested by S̨engör et al. (1988).

The second episode of rifting off northwest Australia is dated by Legs 122 and 123 as between Carnian and Barremian (von Rad et al., 1989; U. von Rad, pers. comm., 1990). An unconformity on the Wombat Plateau between the upper Carnian and Norian marks the onset of a new episode of block faulting that remained active until the Rhaetian on the basis of the incomplete data from the Wombat Plateau, where there is no Jurassic section. In the Wombat Plateau, the intensity of normal faulting seems greater in the Carnian and older section than in the Norian (e.g., von Rad et al., 1989, figs. 5 and 6).

The extensional tectonics seems to have continued into the Early Jurassic and was accompanied by intermediate and rhyolitic volcanism dated by the $\mathrm{K}-\mathrm{Ar}$ method as being 213-190 Ma (Norian to Pliensbachian). Normal faulting related to this episode had stopped completely by the Late Jurassic and Oxfordian shales blanket the block-faulted terrain (von Rad et al., 1989; also von Stackelberg et al., 1980, fig. 8).

We believe that it is likely that breakup had occurred before the Oxfordian. How much earlier than the Oxfordian is difficult to tell on the basis of the data from the Australian 
margin, but the fragment that departed from here, the Lhasa block (t), had been facing ocean at least during the Portlandian. Because the main Neo-Tethyan subduction began south of the Lhasa block (t) in the Callovian to Portlandian (Honegger et al., 1982; Girardeau et al., 1984b), a sizable ocean must have existed by the Late Jurassic between it and the northwest Australian margin.

Remarkable similarities exist between the paleogeographic evolution of the Lhasa block ( $\mathrm{t}$ ) and the northwestern margin of Australia (Figs. 4 to 11). Both regions were distended in the Permian and both were the site of Triassic intermediate composition volcanism. Both contain Carnian clastics along a rifted margin, although the Lhasa clastics range from shallowwater to deep-water turbidites as opposed to the pro-delta deposits of the Exmouth Plateau (Leg 122 Shipboard Scientific Party, 1989). On the Mount Victoria Land segment of the Lhasa block there is a stratigraphic gap between the Carnian and the Aptian, which is similar to the Rhaetian to Late Jurassic gap on the Wombat Plateau.

We thus conclude that the breakup of the Lhasa block (t), at least its extreme eastern part now represented by the Mount Victoria Land area, occurred not much later than the Late Triassic-Early Jurassic and not in the Late Jurassic as assumed by most authors. This inference receives support from an analogous situation in the Himalayas. There, Middle Jurassic extensional tectonism also occurred, as evidenced by the rapid drowning of the Kioto platform, well after the departure of the Lhasa block from India (Gaetani and Garzanti, 1989, in press).

We speculate, on the basis of andesitic volcanics of Triassic age on the Lhasa block and also on the Australian margin, that this second episode may also have been one of back-arc rifting similar to the Permian episode.

The final breakup that created the present margin in northwest Australia was a middle Early Cretaceous affair. As seen in Table 1 only the Sikuleh-Natal $\left(z^{\prime}+z^{\prime \prime}\right)$ block could have rifted off at this time, as all other blocks had either already collided with Eurasia or subduction of Neo-Tethys along their present southern margins already had commenced. As reviewed above, the limited paleomagnetic data from the Sikuleh area are consistent with this interpretation. Unfortunately, the stratigraphy of the Sikuleh-Natal region is poorly understood. The basement in the Sikuleh area is metamorphic, consisting of probable Paleozoic quartzites and phyllites intruded mainly by Mesozoic calc-alkaline granitoids and Tertiary rhyolites and molybdenum-bearing breccia pipes (D. E. Karig, pers. comm., 1986; Metcalfe, 1990). In the upper parts (lower Permian) carbonates dominate and the whole section is truncated above by an unconformity.

The lower Mesozoic in both the Sikuleh $\left(z^{\prime}\right)$ and Natal $\left(z^{\prime \prime}\right)$ fragments is unknown, although the "wackes" underlying the Late Jurassic-Early Cretaceous shallow-water limestones (cf. Cameron et al., 1980) may be of early Mesozoic age as argued above.

The later Mesozoic history until the Early Cretaceous inclusive of the Sikuleh-Natal fragment $\left(z^{\prime}+z^{\prime \prime}\right)$ is better known from Padang. Here, the increasing clastic influx into the previously quiet carbonate sedimentation and coeval volcanism (Yancey and Alif, 1977) indicate the onset of tectonic unrest, and the Early Cretaceous radiolarian-bedded cherts document rapid deepening of the environment of deposition, suggesting that the previous onset of tectonism was likely a manifestation of beginning extension. Thus, the Sikuleh-Natal fragment $\left(z^{\prime}+z^{\prime \prime}\right)$ probably began separating from a preexisting shelf sometime in the Early Cretaceous, at a time when a fragment broke up from the northwest Australian margin.
We thus postulate, following Metcalfe's (1990) suggestion, that the Sikuleh-Natal fragment, $\left(z^{\prime}+z^{\prime \prime}\right)$ with its possible continuation in south Sumatra and in western and northwestern Java (e.g., Hamilton, 1979, p. 100), was the continental object that departed from northwestern Australia in the Early Cretaceous. The volcanism that accompanied this rifting is recorded both in the tuffs of the Indarung Formation in Padang, West Sumatra, and in the Early Cretaceous volcaniclastics reached at Site 766 in the western foot of the Exmouth Plateau and in the Scott Plateau volcanics recorded at Site 765 of Leg 122. The Albian basaltic volcanism in the Himalayas (Gaetani and Garzanti, 1989, in press) may have been a somewhat later manifestation of the same event farther west.

One biotite granite intrusion of $104.7+1.3 \mathrm{Ma}$ (K-Ar on biotite) is also known from the Sikuleh-Natal fragment in central-west Sumatra (near Mompang Jae: D. E. Karig, pers. comm., 1985).

Following the late Berriasian to Hauterivian ocean-floor accretion in the Argo Abyssal Plain (von Rad et al., 1989) and in areas farther to the southwest no more rifting events scarred the northwest margin of Australia and no more major continental block became accreted to the margin of Asia along the southwest periphery of Sundaland. The former has continued its quiet subsidence while the latter became the theater of major subduction that has since been constructing a major subduction-accretion complex.

\section{CONCLUSIONS}

The main conclusions of this paper may be itemized as follows:

1. The fragment that rifted off the northwestern Australian continental margin in the middle Early Cretaceous was likely the Sikuleh-Natal fragment (z) that is now located south of the Woyla suture in Sumatra. This fragment collided with the rest of Sumatra in the Late Cretaceous.

2. The Mount Victoria Land block of Burma is an integral part of the Helmand (m)-South Pamir-Lhasa-Central Burma (t) block. It rifted and drifted away from northwestern Australia before the Oxfordian, and most likely during the latest Norian-Rhaetian.

3. The inception of the Westralian superbasin in northwestern Australia during the late Carboniferous-early Permian was likely a consequence of the rifting of the Central PamirWestern Qangtang $\left(s^{\prime}\right)$-Sibumasu $\left(s^{\prime \prime}\right)$ block away from northern Gondwana-Land. The Hainan Island "terranes" were an integral part of this block that later became separated from it during syn-collisional tectonism within Eurasia. A corollary to this model is that the Huanan and the Annamia blocks constituted a single entity until the syn-collisional disruption that isolated the Hainan "terranes."

4. The northwestern Australian continental margin was a site of repeated rifting between the latest Carboniferous and the Early Cretaceous. During this time, thin strips of continental crust calved off the continental margin creating successive ocean basins behind them. It seems that all of these strips were magmatic arcs and that the basins opened behind them were probably back-arc basins. In the Early Cretaceous the volcaniclastics encountered in the western foot of the Exmouth Plateau may be those that came off the Sikuleh-Natal arc (distal turbidites). The Early Cretaceous Sikuleh-Natal arc may have been located on the same convergent boundary, along which the peri-Arabian giant supra-subduction zone opholites of Oman, Neyriz, Kermanshah, Cilo, and Kızıldağ-Baer Bassit were generated. The Albian basaltic volcanism in the Himalayas may have had the same source. 
5. Northwestern Australia has had a geological history similar to eastern Australia/Tasman Sea, in which successive thin continental strips were also ripped off the continent by the peri-Pacific subduction systems since the late Paleozoic.

6. It is possible to make a one-to-one comparison between the rifting events in northwestern Australia and subsequent collision of the rifted fragments with Eurasia and thus to correlate the growth of Asia with the diminution of Australia.

\section{ACKNOWLEDGMENTS}

We wish to thank Co-chiefs Bilal Ul Haq and Ulrich von Rad, ODP Staff Scientist Suzanne O'Connell, and fellow shipboard scientists on Leg 122 . We would like to thank Prof. Illhan Kayan, the rector of ITU, for funding N. Görür to participate in ODP. Funding for post-cruise meeting at Texas A\&M University was provided by TUBITAK. We are indebted to Dr. Ian Metcalfe for fruitful discussions on the geology of Southeast Asia. Discussions with Prof. K. J. Hsü on the geology of China are gratefully acknowledged. We thank Serdar Engin and Haldun Okuroğulları for their assistance in preparation of the manuscript. Thanks are extended to Dr. Remzi Akkök, general director of Akşan Consulting and Engineering Co., for having the initial text typed and mailed. Final typescript was prepared by the Sürat Daktilo Co., Istanbul.

\section{REFERENCES}

Anonymous, 1980. Guidebook to South Tibet: Beijing (Academia Sinica).

Audley-Charles, M. G., 1978. The Indonesian and Philippine Archipelagos. In Moullade, M., and Nairn, A.E.M. (Eds.), The Phanerozoic Geology of the World: The Mesozoic A., Amsterdam (Elsevier), 2:165-202.

1984. Cold Gondwana, warm Tethys and the Tibetan Lhasa block. Nature, 310:165-166.

1988. Evolution of southern margin of Tethys (North Australian region) from early Permian to late Cretaceous. In Audley-Charles, M. G., and Hallam, A. (Eds.), Tethys and Gondwana. Geol. Soc. Spec. Publ. London, 37:79-100.

Baker, P. E., Rea, W. J., Skarmeta, J., Caminos, R., and Rex, D. C., 1981. Igneous history of the Andean Cordillera and Patagonian Plateau around latitude $46^{\circ} \mathrm{S}$. Philos. Trans. R. Soc. London, A303:105-149.

Barber, A. J., 1985. The relationship between the tectonic evolution of Southeast Asia and hydrocarbon occurrences. In Howell, D. G. (Ed.), Tectonostratigraphic Terranes of the Circum-Pacific Region. Circum-Pacific Council for Energy and Mineral Resources Earth Science Ser., 1:523-528.

Barber, P. M., 1988. The Exmouth Plateau deep water frontier: a case history. In Purcell, P. G., and Purcell, R. R. (Eds.), The North West Shelf, Australia: Proc. Pet. Expl. Soc. Aust. Symp., 173-187.

Baud, A., 1989. The western end of the Tibetan Plateau. In Sengör, A.M.C. (Ed.), Tectonic Evolution of the Tethyan Region: Dordrecht (Kluwer Academic Publ.), 505-506.

Baud, A., Arn, R., Bugnon, P., Crisinel, A., Dolivo, E., Escher, A., Hammerschlag, J. G., Marthaler, M., Masson H., Steck, A., and Tiéche, J. C., 1982. Le contact Gondwana-Péri-Gondwana dans le Zanskar oriental (Ladakh, Himalaya). Bull. Soc. Geol. Fr., 24:341-361.

Bender, F., 1983. Geology of Burma: Berlin (Gebrüder Borntraeger).

Bhalla, S. N., 1983. India. In Moullade, M., and Nairn, A.E.M. (Eds.), The Phanerezoic Geology of the World: Amsterdam (Elsevier), 2:305-352.

Bhatia, M. R., Thomas, M., and Boirie, J. M., 1984. Depositional framework and diagenesis of the Late Permian gas reservoirs of the Bonaparte Basin. APEA J., 24:299-313.

Bignell, J. D., and Snelling, N. J., 1977. Geochronology of Malayan granites. Overseas Geol. Miner. Resour., 47.

Bordet, P., Colchen, M., Krummenacher, D., Le Fort, P., Mouterde, R., and Rémy, J. M., 1971. Recherches Géologiques dans l'Himalaya du Népal, Région de La Thakkhola: Paris (CNRS).
Bordet, P., Colchen, M., and Le Fort, P., 1972. Some features of the geology of the Annapurna Range, Nepal, Himalaya. Himalayan Geol., 2:537-563.

Bradshaw, M. T., Yeates, A. N., Beynon, R. M., Brakel, A. T., Langford, R. P., Totterdell, J. M., and Yeung, M., 1988. Paleogeographic evolution of the North West Region. In Purcell, P. G., and Purcell, R. R. (Eds.) The North West Shelf, Australia: Proc. Pet. Expl. Soc. Aust. Symp., 29-54.

Brunnschweiler, R. O., 1966. On the geology of Indaburman Ranges. J. Geol. Soc. Aust., 13:137-194.

Bunopas, S., 1981. Paleogeographic history of Western Thailand and adjacent parts of South-East Asia: a plate tectonics interpretation [Ph.D. thesis]. Victoria Univ. of Wellington, New Zealand.

1983. Paleozoic succession in Thailand. Workshop on Stratigraphic Correlation of Thailand and Malaysia, Haad Yai, Thailand, 39-76.

Bunopas, S., Somkiate, M., and Vella, P., 1989a. Paleozoic and early Mesozoic rotation and drifting Shan-Thai from Gondwana-Australia. Repts. Abstracts 4th Inter. Symp. on Pre-Jurassic East Asia IGCP Proj. 224, 1:61-62.

1989b. Mesozoic paleopoles and paleolatitudes from Thailand and their significant bearing on the Khorat (Indosinian and Cimmerian) orogeny. Repts. Abstracts 4th Inter. Symp. on PreJurassic East Asia IGCP Proj. 224, 1:63-64.

Bunopas, S., and Vella, P., 1989. "Pebbly Mudstones" a composite assemblage of ice-rafted sediments of the western rifted marginal basin on Shan-Thai while drifting away from Gondwana during the Upper Paleozoic. Repts. Abstracts 4th Inter. Symp. on PreJurassic East Asia IGCP Proj. 224, 1:54-56.

Burg, J.-P., Proust, F., Tapponnier, P., and Chen Guo Ming, 1983. Deformation phases and tectonic evolution of the Lhasa block (southern Tibet, China). Eclogae Geol. Helv., 76:643-665.

Burrett, C. F., 1974. Plate tectonics and fusion of Asia. Earth Planet. Sci. Lett., 21:181-189.

Burrett, C. F., and Stait, B., 1987. China and southeast Asia as part of the Tethyan margin of Cambro-Ordovician Gondwanaland. In McKenzie, K. G. (Ed.), Shallow Tethys 2: Rotterdam (A. A. Balkema), 65-78.

Cameron, N. R., Clarke, M.C.G., Aldiss, D. T., Aspden, J. A., and Djunuddin, A., 1980. The geological evolution of northern Sumatra. Proc. Indonesian Petrol. Assoc. 9th Annu. Conf., 149-187.

Cande, S. C., LaBrecque, J. L., Larson, R. L., Pitman, W. C., III, Golovchenko, X., and Haxby, W. F., 1989. Magnetic Lineations of the World's Oceans. Map (1:27,400,000). AAPG.

Casnedi, R., and Mosna, S., 1979. Upper Paleozoic and Mesozoic sedimentary rocks in the Upper Karambar valley (Pakistan-Afghan border): Riv. Ital. Paleontol. Stratigr., 85:11-12.

Casnedi, R., and Nicora, A., 1985. Short notes on the Shimshal valley geology (Western Karakorum-Pakistan): Riv. Ital. Paleontol. Stratigr., 90:463-480.

Chang, C., Nansheng, C., Coward, M. P., Wanming, D., Dewey, J. F., Gansser, A., Harris, N.B.W., Chengwei, J., Kidd, W.S.F., Leeder, M. R., Huan Li, Jinlu, L., Changiie, L., Howjun, M., Molnar, P., Yun, P., Yusheng, P., Pearce, J. A., Shackleton, R. M., Smith, A. B., Yiyin, S., Ward, M., Watts, D. R., Juntao, X., Ronghua, X., Jixiang, Y., and Yuquan, Z., 1986. Preliminary conclusions of the Royal Society and Academia Sinica 1985 geotraverse of Tibet. Nature, 323:501-507.

Chang, C., Yu-Sheng, P., and Yi-Ying, S., 1989. The tectonic evolution of Qinghai-Tibet Plateau: a review. In S̨engör, A.M.C. (Ed.), Tectonic Evolution of the Tethyan Region: Dordrecht (Kluwer Academic Publ.), 415-476.

Charvet, J., and Faure, M., 1989. Some new considerations on the evolution of Southeast China. Repts. Abstr. 4th Inter. Symp. on Pre-Jurassic East Asia IGCP Project 224, 1:19-20.

Chen, J., 1986. Mesozoic transgressions, regressions and bivalve provinces in China. In Huang, J. (Ed.), Proc. Symp. Mesozoic Cenozoic Geol. in Connection of the 60th Anniv. Geol. Soc. China: Beijing (Geol. Publ. House), 31-48.

Cheng, C., 1985. Heng Yang Basin. Escap Atlas of Stratigraphy IV. People's Republic of China. United Nations, Mineral Resour. Dev. Ser., 52:35-38. 
Chengdu Institute of Geology and Mineral Resources, 1989. Geological Map of the Qinghai-Xizang (Tibet) Plateau and Adjacent Areas: Chengdu.

Cobbing, E. J., Mallick, D.I.J., Pitfield, P.E.J., and Teoh, L. H., 1986. The granites of the southeast Asian tin belt. J. Geol. Soc. London, 143:537-550.

Crostella, A., and Barter, T., 1980. Triassic-Jurassic depositional history of the Dampier and Beagle Sub-basins, Northwest Shelf of Australia. APEA J., 20:25-33.

Datta, N. R., Mitra, N. D., and Bandyopadhyay, S. K., 1983. Recent trends in the study of Gondwana Basins of Peninsular and extrapeninsular India. Petrol. Asia J., 6:159-169.

Desio, A., 1979. Geologic evolution of the Karakorum. In Farah, A., De Jong, K. A. (Eds.), Geodynamics of Pakistan. Geol. Surv. Pakistan, 111-124.

Dewey, J. F., Shackleton, R. M., Chang, C., Sun, Y., 1988. The tectonic evolution of the Tibetan Plateau. Philos. Trans. R. Soc. London, 327:379-413.

Douvillé, H., 1915. Les calcaires à Orbitolines et à radiolites du Thibet. In Hennig, A. (Ed.), Zur Petrographie und Geologie von Südwest-Tibet (Southern Tibet, V. V.): Stockholm (Kongl. Boktryckerite $P$. A. Norstedt and Soner), 145-147.

Exon, N. F., von Rad, U., and von Stackelberg, U., 1982. The geological development of the passive margins of the Exmouth Plateau off northwest Australia. Mar. Geol., 47:131-152.

Exon, N. F., and Willcox, J. B., 1978. Geology and petroleum potential of the Exmouth Plateau area off Western Australia. AAPG Bull., 62:40-72.

Fontaine, H., and Workman, D. R., 1978. Review of the geology and mineral resources of Kampuchea, Laos and Vietnam. In Natulaya, P. (Ed.), Proc. Third Regional Conf. Geol. Mineral Resour. of Southeast Asia, 541-601.

Fromaget, J., 1934. Observations et reflexions sur la géologie stratigraphique et structurale de l'Indochine. Bull. Soc. Geol, Fr., Sér. $5,4: 101-164$.

Fuchs, G., 1979. On the geology of Western Ladakh. Jahrb. Geol. Bundesanst Austria, 122:513-540.

1982. The geology of western Sanskar. Jahrb. Geol. Bunde sant Austria, 125:1-50.

1987. The geology of Southern Zanskar (Ladakh). Evidence for the autochthony of the Tethys Zone of the Himalaya. Jahrb. Geol. Bundesanst Austria, 130:465-491.

Fullerton, L. G., Sager, W. W., and Handschumacher, D. W., 1989. Late Jurassic-Early Cretaceous evolution of the eastern Indian Ocean adjacent to Northwest Australia. J. Geophys. Res., 94:2937-2953.

Gaetani, M., Casnedi, R., Fois, E., Garzanti, E., Jadoul, F., Nicora, A., and Tintori, A., 1986. Stratigraphy of the Tethys Himalaya in Zanskar, Ladakh. Riv. Ital. Paleontol. Stratigr., 91:443-478.

Gaetani, M., and Garzanti, E., 1989. Multicyclic evolution of northwestern margin of Indian Plate. Inter. Geol. Congr. 28th Sess., Washington, Abstr., 1:523-524.

, in press. Multicyclic evolution of the northern margin of the Indian Plate. $A A P G$ Bull.

Gaetani, M., Garzanti, E., Jadoul, F., 1985. Main structural elements of Zanskar, NW Himalaya (India). Rend. Soc. Geol. Ital., 8:3-8.

Gahagan, L. M., Scotese, C. R., Royer, J.-Y., Sandwell, D. T., Winn, J. K., Tomlins, R. L., Ross, M. I., Newman, J. S., Müller, R. D., Mayes, C. L., Lawyer, L. A., and Heubeck, C. E., 1988. Tectonic fabric map of the ocean basins from satellite altimetry data. Tectonophysics, 155:1-26.

Gansser, A., 1964. The Geology of the Himalayas: New York (Wiley). 1980. The significance of the Himalayan suture zone. Tectonophysics, 62:37-52.

Girardeau, J., Marcoux, J., Allégre, C. J., et al., 1984a. Tectonic environment and geodynamic significance of the Neo-Cimmerian Donqiao ophiolite, Bangong Nu Jiang suture zone, Tibet, China. Nature, 307:27-31.

Girardeau, J., Marcoux, J., and Yougong, Z., 1984. Lithologic and tectonic environment of the Xigaze ophiolite (Yarlung Zangbo suture zone, Southern Tibet, China), and kinematics of its emplacement. Eclogae Geol. Helv., 77:153-170.
Gunn, P. J., 1988. Bonaparte Basin: evolution and structural framework. In Purcell, P. G., and Purcell, R. R. (Eds.), The North West Shelf, Australia. Pet. Expl. Soc. Aust. Symp., 275-285.

Hahn, L., 1982. The Triassic in Thailand. Geol. Rundsch., 71:10411056 .

Haile, N. S., 1979. Paleomagnetic evidence for rotation and northward drift of Sumatra. J. Geol. Soc. London, 136:541-545.

Hamilton, W. B., 1979. Tectonics of the Indonesian Region. Geol. Surv. Prof. Pap. U.S., 1078.

Haq, B. U., and Van Eysinga, F.W.B., 1987. Geological Time Table (4th ed., rev.): Amsterdam (Elsevier).

Harbury, N. A., Jones, M. E., Audley-Charles, M. G., Metcalfe, I., and Mohamed, K. R., 1990. Structural evolution of Mesozoic Peninsular Malaysia. J. Geol. Soc. London, 147:11-26.

Helmcke, D., 1983. On the Variscan evolution on Central Mainland Southeast Asia. Earth Evol. Sci., 4:309-319.

Henning, A., 1915. Zur Petrographie und Geologie von Südwest Tibet (Vol. 5): Stockholm (Lithogr. Inst. Gen. Staff Swed. Army).

Hocking, R. M., 1988. Regional geology of the northern Carnarvon Basin. In Purcell, P. G., and Purcell, R. R. (Eds.), The North West Shelf, Australia: Proc. Pet. Expl. Soc. Aust. Symp., 97-114.

Hocking, R. M., Moors, H. T., and Van Der Graaff, W.J.E., 1987. The geology of the Carnarvon Basin, W.A. Bull. Geol. Surv. West. Aust., 133.

Honegger, K., Dietrich, V., Frank, W., Gansser, A., Thöni, M., and Trommsdorff, V., 1982. Magmatism and metamorphism in the Ladakh Himalayas (the Indus-Tsangpo suture zone). Earth Planet. Sci. Lett., 60:253-292.

Horstman, E. L., and Purcell, P. G., 1988. The offshore Canning Basin-a review. In Purcell, P. G., and Purcell, R. R. (Eds.), The North West Shelf, Australia: Proc. Pet. Expl. Soc. Aust. Symp., 253-258.

Hsü, K. J., Sun, S., and Li, J., 1989. Mesozoic suturing in the Huanan Alps and tectonic assembly of south China. In Sengör, A.M.C. (Ed.), Tectonic Evolution of the Tethyan Region: Dordrecht (Kluwer Academic Publ.), 551-566.

Hu, J., Xu, S., Tong, X., and Wu, H., 1989. The Bohai Bay Basin. In Hsü, K. J. (Ed.), Sedimentary Basins of the World (Vol. 1): Amsterdam (Elsevier), 89-105.

Hutchison, C. S., 1989a. The Paleo-Tethyan realm and Indosinian orogenic system of southeast Asia. In Sengör, A.M.C. (Ed.), Tectonic Evolution of the Tethyan Region: Dordrecht (Kluwer Academic Publ.), 585-643.

1989b. Geological Evolution of South-East Asia: Oxford (Clarendon Press).

Jain, A. K., 1981. Stratigraphy petrography and paleogeography of the late Paleozoic diamictites of the Lesser Himalaya. Sediment. Geol., 30:43-78.

Jia, R. S., Huang, Y. Y., Ye, D. S., and Zhong, H. M., 1985. Talimu Basin. Escap Atlas of Stratigraphy IV. People's Republic of China. United Nations, Mineral Resour. Dev. Ser., 52:75-81.

Jiazhen, Z., 1985. Hubei-Bohai Gulf Basin. Escap Atlas of Stratigraphy IV. People's Republic of China. United Nations, Mineral Resour. Dev. Ser., 52:22-27.

Jiongkun, Z., Yougang, Y., and Xigi, Z., 1985. Subei-South Yellow Sea Basin. Escap Atlas of Stratigraphy, IV. People's Republic of China. United Nations, Mineral Resour. Dev. Ser., 52:28-34.

Jixiang, Y., Juntao, X., Chengjie, L., and Huan, L., 1988. The Tibetan plateau: regional stratigraphic context and previous work. Report of the 1985 Royal Society-Academia Sinica. Geotraverse of the Qinghai-Xizang Plateau. Philos. Trans. R. Soc. London, A327:5-52.

Khuc, V., 1986. Triassic in Indochina. Proc. First Conf. Geol. Indochina, 1:111-126.

Khuc, V., Bao, N. X., and Cu, L. V., 1986. Stratigraphic correlation between sedimentary basins of the Escap Region. Escap Atlas of Stratigraphy VI. Socialist Republic of Vietnam. United Nations, Mineral Resour. Dev. Ser., 54.

Kobayashi, T., 1968. The Cretaceous non-marine pelecypods from the Naw Phung dam site in the northeastern part of the Koharat Plateau, Thailand, with a note on the Triganioidae: contributions to the geology and palaeontology of Southeast Asia, XLVII. Geol. Palaeontol. Southeast Asia, 4:109-138. 
Larson, R. L., 1977. Early Cretaceous breakup of Gondwanaland off Western Australia. Geology, 5:57-60.

Larson, R. L., Mutter, J. C., Diebold, J. B., Carpenter, G. B., and Symonds, P., 1979. Cuvier Basin: a product of ocean crust formation by Early Cretaceous rifting off western Australia. Earth Planet. Sci. Lett., 45:105-114.

Leg 122 Shipboard Scientific Party, 1989. Ocean drilling programbreakup of Gondwanaland. Nature, 377:209-210.

Leg 123 Shipboard Scientific Party, 1989. The birth of the Indian Ocean. Nature, 337:506-507.

Lexique Stratigraphique International, 1963. Asie. Fasc. 1 (Vols. 1 and 2). République Populaire Chinoise. Paris (Cent. Nat. Rech. Sci. 1971. Asie. Fasc. 1 (Vol. 3). République Populaire Chinoise. Paris (Cent. Nat. Rech. Sci.).

Liew, T. C., and Page, R. W., 1985. U-Pb zircon dating of granitoid plutons from the West Coast province of Peninsular Malaysia. $J$. Geol. Soc. London, 142:515-526.

Lin, J.-L. and Fuller, M., in press. Paleomagnetism, North China and South China collision, and the Tan-lu fault: Philos. Trans. R. Soc. London.

Longyun, Li, 1985. Eerdosi Basin. Escap Atlas of Stratigraphy IV. People's Republic of China. United Nations, Mineral Resourc. Dev. Ser., 52:53-62.

Marcoux J., De Wever P., Nicolas, A., Girardéau, J., Xuchanq, X., Chengfa, C., Naiwen, W., Yougonq, Z., Bassoullet, J. P., Colchen, M., and Mascle, G., 1982. Preliminary report on depositional sediments on top of volcanic member: the Xigaze ophiolite (Yarlunq Zangbo suture zone, Xizanq, China). Ofioliti, 6:31-32.

Marcoux, J., Girardeau, J., Fourcade, E., Bassoullet, J.-P., Phillip, J., Jaffrezo, M., Xachang, X., and Chang, C., 1987. Geology and biostratigraphy of the Jurassic and Lower Cretaceous series to the north of the Lhasa Block (Tibet, China). Geodin. Acta (Paris), $1: 313-325$.

Metcalfe, I., 1986. Late Paleozoic paleogeography of Southeast Asia: some stratigraphical, paleontological and paleomagnetic constraints. Bull. Geol. Soc. Malays., 19:153-164.

1988. Origin and assembly of Southeast Asian continental terranes. In Audley-Charles, M. G., and Hallam, A. (Eds.), Gondwana and Tethys. Geol. Soc. Spec. Publ. London, 37:101118.

1990. Allochthonous terrane processes in Southeast Asia. Philos. Trans. R. Soc. London, 331:625-640.

Mitchell, A.H.G., 1981. Phanerozoic plate boundaries in mainland S.E. Asia, the Himalayas and Tibet. J. Geol. Soc. London, 138:109-122.

1989. The Shan plateau and western Burma: Mesozoiccenozoic plate boundaries and correlations with Tibet. In Şengör, A.M.C. (Ed.), The Tectonic Evolution of the Tethyan Region: Dordrecht (Kluwer Academic Publ.), 567-584.

Mitchell, A.H.G., Marshall, T. R., Skinner, A. C., Baker, M. D., Amos, B. J., and Bateson, J. H., 1977. Geology and exploration geochemistry of the Yadanatheingi and Kyaukme-Longtawko areas, Northern Shan States, Burma. Overseas Geol. Miner. Resour., 51:1-35.

Molnar, P., Burchfiel, B. C., Zhao, Z., Liang, K., Wang, S., and Huang, M., 1987. Geologic evolution of Northern Tibet: results of an expedition to Ulugh Muztagh. Science, 235:299-304.

Mory, A. J., 1988. Regional geology of the offshore Bonaparte Basin. In Purcell, P. G., and Purcell, R. R. (Eds.), The North West Shelf, Australia. Pet. Expl. Soc. Aust. Symp., 287-309.

Murphy, R. W., 1987. Southeast Asia: a tectonic triptych. In Horn, M. K. (Ed.), Trans. Fourth Circum-Pacific Energy Mineral Resour. Conf.: Circum-Pacific Council for Energy end Mineral Resources, 395-400.

Naiwan, W., Si'en, W., Guifang, L., Bassoullet, J., Colchen, M., Mascle, L., and Jaeger, J., 1981. The marine-terrestrial alternating Jurassic and Cretaceous sequences in the Lhasa area, Tibet. In Jiqing, H. (Ed.), Proc. Symp. Mesozoic Cenozoic Geol. in Connection of the 60th Anniver. Geol. Soc. China: Beijing (Geol. Publ. House), 185-200.

Norin, E., 1976. The "Black Slates" formations in the Pamirs, Karakorum and Western Tibet. In Geotettonica delle Zone Orogeniche del Kashmir Himalaya Karakorum-hindu Kush-Pamir. Roma (Academia Nazionale dei Lincei), 245-264.
1979. The relationships between the Tibetan platform and the Tarim basin. Bull. Geol. Inst. Univ. Uppsala, 8:17-34.

Norton, I. O., and Sclater, J. G., 1979. A model for the evolution of the Indian Ocean and the break-up of Gondwanaland. J. Geophys. Res., 84:6803-6830.

Parry, J. C., and Smith, D. N., 1988. The Barrow and Exmouth sub-basins. In Purcell, P. G., and Purcell, R. R. (Eds.), The North West Shelf, Australia. Pet. Expl. Soc. Aust. Symp., 129-145.

Pearce, J. A., and Deng, W., 1988. The ophiolites of the Tibet Geotraverses, Lhasa to Golmud (1985) and Lhasa to Kathmandu (1986). Philos. Trans. R. Soc. London, 327:215-238.

Pearce, J. A., and Mei, H., 1988. Volcanic rocks of the 1985 Tibet Geotraverse: Lhasa to Golmud: Philos. Trans. R. Soc. London, 327:169-201.

Phan, T. T., and Tran, V. T., 1989. Pre-Jurassic thermodynamic metamorphism in Vietnam. Repts. Abstr. 4th Inter. Symp. PreJurassic Evolution of Eastern Asia, 1:50-51.

Pitakpaivan, K., and Chonglakmani, C., 1978. Continental Mesozoic Basins of Thailand. Escap Atlas of Stratigraphy I. Burma, Malaysia, Thailand, Indonesia, Philippines. United Nations, Mineral Resour. Dev. Ser., 44:45-50.

Powell, D. E., 1976. The geological evolution of the continental margin off northwest Australia. APEA J., 16:13-23.

Rahman, H., 1963. Geology of petroleum in Pakistan. 6th World Petrol. Congr., Francfort/Main. Sect. I, Pap. 31 PD. 31 Pakistan.

Rajah, S. S., and Yin, E. H., 1980. Summary of the geology of the Central Belt Peninsular Malaysia. Geol. Palaeontol. Southeast Asia, 21:319-342.

Rao, C.S.R., and Mitra, N. D., 1978. Sedimentation and tectonics of Gondwana basins of Peninsular India. In Nutalaya, P. (Ed.), Geology and Mineral Resources of Southeast Asia: Bangkok (Asian Inst. of Technology), 85-90.

Remy, J. M., 1975. Geology of Nepal West of Nepal Himalaya: Paris (Cent. Nat. Rech. Sci.).

Reynolds, P. H., Brookfield, M. E., and McNutt, R. H., 1983. The age and nature of Mesozoic-Tertiary magmatism across the Indus suture zone in Kashmir and Ladakh (N.W. India and Pakistan). Geol. Rundsch., 72:981-1004.

Ridd, M. F., 1978. Thailand. In Moullade, M., and Nairn, A.E.M. (Eds.), The Phanerozoic Geology of the World (Vol. 2): Amsterdam, (Elsevier Sci. Publ.), 145-161.

1980. Possible Paleozoic drift of SE asia and Triassic collision with China. J. Geol. Soc. London, 137:635-640.

Rowley, D. B., Lottes, A. L., Nie, S. Y., Yao, J. P., and Ziegler, A. M., 1986. Mesozoic-Cenozoic tectonic evolution of China and adjacent Asia. 1986 Geodynamics Symp., Mesozoic and Cenozoic Plate Reconstructions, Texas A\&M Univ., Abstracts.

Rowley, D. B., Ziegler, A. M., and Nie, G., 1989. Mesozoic overthrust tectonics in south China: discussion. Geology, 17:384-386.

Roybarman, A., 1983. Geology and hydrocarbon prospects of West Bengal. Petrol. Asia J., 6:51-56.

Rukhin, L. B., 1960. Paleogeografiya Aziatskogo materika v mesozoe. Dokl. Soviet. Geol. Prob., 12:85-98.

Sastry, C.V.S., Singh, G., Bhasin, A. L., Badola, S. N., Pati, P. B., and Chaturvedi, R. K., 1984. Possible leads for future exploration in Cambay Basin. Pet. Asia J., 7:71-81.

Scotese, C. R., Ghagan, L. M., and Larson, R. L., 1988. Plate tectonic reconstructions of the Cretaceous and Cenozoic ocean basins. Tectonophysics, 155:27-48.

Scotese, C. R., Royer, J. Y., Mueller, R. D., Nurnberg, D., Mayes, C. L., Lawver, L. A., Tomling, R. L., Newman, J. S., Heubeck, C. E., Winn, J. K., Beckly, L., and Sclater, J. G., 1987. Atlas of Mesozoic and Cenozoic Plate Tectonic Reconstructions. Paleoceanographic mapping project, Inst. for Geophys., Univ. of Texas, Tech. Rep. 90.

Searle, M. P., 1983. Stratigraphy, structure and evolution of the Tibetan-Tethys zone in Sanskar and the Indus suture zone in the Ladakh Himalaya. Trans. R. Soc. Edinburgh, Earth Sci., 73:205219.

Şengör, A.M.C., 1979. Mid-mesozoic closure of Permo-Triassic Tethys and its implications. Nature, 279:590-593.

1981. The evolution of Paleo-Tethys in the Tibetan segment of the Alpides. In Proc. Symp. Qinghai-Xizang (Tibet) Plateau I. Beijing (Science Press), 51-56. 
1984. The Cimmeride orogenic system and the tectonics of Eurasia. Spec. Pap. Geol. Soc. Am., 195.

1986a. The dual nature of the Alpine-Himalayan System: progress, problems and prospects. Tectonophysics, 127:177-195. , 1986b. Die Alpiden und die Kimmeriden: die verdoppelte Geschichte der Tethys: reply. Geol. Rundsch., 75:203-212.

1987. Tectonics of the Tethysides: orogenic collage development in a collisional setting. Annu. Rev. Earth Planet. Sci., 15:213-244.

Şengör, A.M.C., Altiner, D., Cin, A., Ustaömer, T., and Hsü, K. J., 1988. Origin and assembly of the Tethyside orogenic collage at the expense of Gondwana Land. In Audley-Charles, M. G., and Hallam, A. (Eds.), Gondwana and Tethys. Geol. Soc. Spec. Publ. London, 37:119-181.

Şengör, A.M.C., and Hsü, K. J., 1984. The Cimmerides of eastern Asia: history of the eastern end of Paleo-Tethys. Mem. Soc. Geol. Fr., 147:139-167.

Shicong, G., Jie, Y., Sheng, W., Mingguang, X. U., Fengtion, Y., Xiaodong, C., and Shengbang, J., 1985. Chaidamu Basin. Escap Atlas of Stratigraphy IV. People's Republic of China. United Nations, Mineral Resour. Dev. Ser., 52:1-12.

Shvolman, V. A., 1978. Relicts of the Mesotethys in the Pamirs. Himalayan Geol., 8:369-378.

Stauffer, P. H., 1983. Unraveling the mosaic of Paleozoic crustal blocks in Southeast Asia. Geol. Rundsch., 72:1061-1080. 1985. Continental terranes in Southeast Asia: pieces of which puzzle? In Howell, D. G. (Ed.), Tectono-Stratigraphic Terranes of the Circum-Pacific Region. Circum-Pacific Council for Energy and Mineral Resources, Earth Sci. Ser., 1:529-539.

Stöcklin, J., 1980. Geology of Nepal and its regional frame. J. Geol. Soc. London, 137:1-34.

Sun, Z., Xie, Q., and Yang, J., 1989. Ordos Basin-a typical example of an unstable cratonic interior superimposed basin. In Hsü, K. J. (Ed.), Sedimentary Basins of the World (Vol. 1): Amsterdam (Elsevier), 63-75.

Tapponnier, P., Mercier J. L., Proust F., Andrieux, J., Armijo, R., Bassoullet, J. P., Brunel, M., Burg, J. P., Colchen, M., Dupre, B., Girardeau, J., Marcoux, J., Mascle, G., Matte, P., Nicolas, A., Li, T., Xiao, X., Chang, C., Lin, P., Li, G., Wang, N., Chen, G., Han, T., Wang, X., Den, W., Zhen, H., Sheng, H., Cao, Y., Zhou, J., and Qiu, H., 1981. The Tibetan side of the India-Eurasia collision. Nature, 294:405-410.

Ting, V. K., and Grabau, A. W., 1934. The Permian of China and its bearing on Permian classification. Rep. XVI Inter. Geol. Congr., Washington, 1:663-667.

Tiwari, R. S., Singh, V., Kumar, S., and Singh, I. B., 1984. Palynological studies of the Tethyan sequence in Malla Johar Area, Kumaon Himalaya, India. The Paleobotanist, 32:341-367.

Tran, D. L., 1986. Sketches of the present understanding on the regional geology of the socialist republic of Vietnam. Proc. First Conf. Geol. Indochina, 1:5-21.

Valdiya, K. S., 1983. Lesser Himalayan Geology: crucial problems and controversies. Curr. Sci., 52:839-857.

Van Bemmelen, R. W., 1949. The Geology of Indonesia (Vol. 1): The Hague (Govt. Printing Office).

Veevers, J. J. (Ed.), 1984. Phanerozoic Earth History of Australia: Oxford (Clarendon Press).

1988. Morphotectonics of Australia's north-western margin: a review. In Purcell, P. G., and Purcell, R. R. (Eds.), The North West Shelf, Australia: Proc. Pet. Expl. Soc. Aust. Symp., 173-187.

Veevers, J. J., and Heirtzler, J. R., 1974. Tectonic and paleogeographic synthesis of Leg 27. In Veevers, J. J., Heirtzler, J. R., et al., Init. Repts. DSDP, 27: Washington (U.S. Govt. Printing Office), $1049-1054$.

Veevers, J. J., Heirtzler, J. R., et al., 1974. Init. Repts. DSDP, 27: Washington (U.S. Govt. Printing Office).

von Rad, U., and Exon, N. F., 1983. Mesozoic-Cenozoic sedimentary and volcanic evolution of the starved passive continental margin off northwest Australia. In Watkins, J. S., and Drake, C. L. (Eds.), Studies in Continental Margin Geology: AAPG Mem., 34:253281. von Rad, U., Thurow, J., Haq, B. U., Gradstein, F., Ludden, J., and ODP Leg 122/123 Shipboard Scientific Parties, 1989. Triassic to Cenozoic evolution of the NW Australian continental margin and the birth of the Indian Ocean (preliminary results of ODP Legs 122 and 123). Geol. Rundsch., 78:1189-1210.

von Stackelberg, U., Exon, N. F., von Rad, U., Quilty, P., Shafik, S., Beiersdorf, H., Seibertz, E., and Veevers, J. J., 1980. Geology of the Exmouth and Wallaby Plateaus off northwest Australia: sampling of seismic sequences. BMR J. Aust. Geol. Geophys., 5:113-140.

Wadia, D. N., 1961. Geology of India: London (Macmillan).

Wang, H., 1985. Atlas of the Paleogeography of China: Beijing (Cartographic Pub. House).

Wang, Y.-G., Chen, C.-C., He, G.-X., and Chen, J.-H., 1981. An outline of the marine Triassic in China. Inter. Union Geol. Sci. Pub., 7.

Wielchowsky, C. C., and Young, J. O., 1985. Regional facies variations in Permian rocks of the Phetchabun Fold and Thrust belt, Thailand. Conf. Geol. Miner. Resour. Dev. Northeast Thailand, Khon Kaen University, 41-55.

Willis, I., 1988. Results of exploration, Browse Basin, North West Shelf, Western Australia. In Purcell, P. G., and Purcell, R. R. (Eds.), The North West Shelf, Australia. Pet. Expl. Soc. Aust. Symp., 259-272.

Winkel, R., Ingavat, R., and Helmcke, D., 1983. Facies and stratigraphy of the lower-middle Permian strata of the Petchabun foldbelt in central Thailand. Proc. Workshop Stratigraphic Correlation Thailand and Malaysia 1. Geol. Soc. Thailand, Bangkok/ Geol. Soc. Malaysia, Kuala Lumpur, Tech. Pap., 293-304.

Workman, D. R., 1977. Geology of Laos, Cambodia, South Vietnam and the eastern Thailand. Overseas Geol. Miner. Resour., 50.

$\mathrm{Xu}, \mathrm{W} ., \mathrm{He}, \mathrm{Y}$. , and Yan, Y., 1989. Tectonic characteristics and hydrocarbons of the Hexi corridor. In Hsü, K. J. (Ed.), Sedimentary Basins of the World (Vol. 1): Amsterdam (Elsevier), 53-62.

Yancey, T. E., and Alif, S. A., 1977. Upper Mesozoic strata near Padang, West Sumatra: Bull. Geol. Soc. Malays., 8:61-74.

Yang, Z., 1986. The Permian system. In Allen, P., Oxburgh, E. R., and Skinner, B. J. (Eds.), The Geology of China. Oxford (Clarendon Press), 111-125.

Yang, Z., Wu, S., and Yang, F., 1981. Permo-Triassic boundary in the marine regime of South China. In Creswell, M. M., and Vella, P. (Eds.), Gondwana Five: Rotterdam (A. A. Balkema), 71-77.

Yeates, A. N., Bradshaw, M. T., Dickens, J. M., Brakel, A. T., Exon, N. F., Langford, R. P., Mullholland, S. M., Totterdell, J. M., and Yeung, M., 1986. The Westralian superbasin: an Australian link with Tethys. In McKenzie, K. G. (Ed.), Shallow Tethys 2: Rotterdam (A. A. Balkema), 119-213.

Yichun, H., Deying, S., Yougui, L., Jingxian, Y., Wangping, Z., Peixian, L., Hua, Q., Shaozeng, G., and Fuxiang, G., 1986. Stratigraphical subdivision of non-marine Cretaceous sequences and the Juro-Cretaceous boundary in China. In Jiqing, H. (Ed.), Proc. Symp. Mesozoic Cenozoic Geol. in Connection of the 60th Anniver. Geol. Soc. China: Beijing (Geol. Pub. House), 109-121.

Yin, J.-X., Wu, H.-R., Sun, Y.-Y., Wen, C.-F., and Liu, T.-S., 1983. Study on Himalayan stratigraphy in south Xizang (Tibet). Contrib. Himalayan Geol., 2:59-74.

Yu, Z., 1989. Hainan Island-a terrane from Gondwana. Repts. Abstr. 4th Inter. Symp. Pre-Jurassic East Asia IGCP Project 224, 1:11-12.

Yu, Z., Shi, Y.-S., and Yang, S.-F., 1988. Hainan Island-a fragment of Gondwana. In Wiley, T. J., Howell, D. G., and Wong, F. L. (Eds.), Terrane Analysis of China and the Pacific Rim: CircumPacific Council for Energy and Mineral Resources, Earth Sci. Ser., 13:283-284.

Zhang, Y., Wei, Z., Xu, W., Tao, R., and Chen, R., 1989. The North Jiangsu-South Yellow Sea Basin. In Hsü, K. J. (Ed.), Sedimentary Basins of the World (Vol. 1): Amsterdam (Elsevier), 107-123.

Zhang, Z.-Q., 1984. The Permian system in south China. Newsl. Stratigr., 13:156-174.

Date of initial receipt: 29 May 1990

Date of acceptance: 19 October 1990

Ms 122B-120 